\title{
Assessment of the geomorphic effectiveness of controlled floods in a braided river using a reduced-complexity numerical model
}

\author{
Luca Ziliani $^{1}$, Nicola Surian ${ }^{1}$, Gianluca Botter $^{2}$, and Luca Mao ${ }^{3}$ \\ ${ }^{1}$ Department of Geosciences, University of Padua, Padua, Italy \\ ${ }^{2}$ Department of Civil, Environmental and Architectural Engineering, University of Padua, Padua, Italy \\ ${ }^{3}$ School of Geography, University of Lincoln, Lincoln, UK
}

Correspondence: Nicola Surian (nicola.surian@unipd.it)

Received: 13 August 2019 - Discussion started: 30 September 2019

Revised: 30 April 2020 - Accepted: 14 May 2020 - Published: 22 June 2020

\begin{abstract}
Most Alpine rivers have undergone significant alterations in flow and sediment regimes. These alterations have notable effects on river morphology and ecology. One option to mitigate such effects is flow regime management, specifically through the reintroduction of channel-forming discharges. The aim of this work is to assess the morphological changes induced in the Piave River (Italy) by two distinct controlled-flood strategies, the first characterized by a single artificial flood per year and the second by higher-magnitude but less frequent floods. This work involved applying a two-dimensional reduced-complexity morphodynamic model (CAESAR-LISFLOOD) to a $7 \mathrm{~km}$ long reach, characterized by a braided pattern and highly regulated discharges. Numerical modelling allowed the assessment of morphological changes for four long-term scenarios (2009-2034). The scenarios were defined considering the current flow regime and the natural regime, which was estimated by a stochastic physically based hydrologic model. Changes in channel morphology were assessed by measuring active-channel width and braiding intensity. A comparison of controlled-flood scenarios to a baseline scenario (i.e. no controlled floods) showed that artificial floods had little effect on channel morphology. More channel widening (13.5\%) resulted from the high-magnitude flood strategy than from the application of the other strategy $(8.6 \%)$. Negligible change was observed in terms of braiding intensity. The results indicate that controlled floods do not represent an effective solution for morphological recovery in braided rivers with strongly impacted flow and sediment regimes.
\end{abstract}

\section{Introduction}

Human activities in riverine areas (i.e. river damming and engineering, gravel mining and land use change in the drainage basin) have historically led to notable changes in flow regimes (Gore and Petts, 1989; Poff et al., 1997, 2007; Magilligan and Nislow, 2005; Zolezzi et al., 2011; Magilligan et al., 2013; Ferrazzi and Botter, 2019) and in the ecological (Collier, 2002; Céréghino et al., 2004; Paetzold et al., 2008; McDonald et al., 2010; Overeem et al., 2013; Espa et al., 2015) and geomorphic functioning of river systems (Hicks et al., 2003; Petts and Gurnell, 2005; Melis, 2011; Ziliani and Surian, 2012; Magilligan et al., 2013; Mueller et al., 2014; Lobera et al., 2016). Dam construction is now considered a viable strategy to meet energy and water demands due to climate change and population growth (World Bank, 2009; Lehner et al., 2011). As outlined by Overeem et al. (2013), large reservoirs with volumes greater than $0.5 \mathrm{~km}^{3}$ intercept globally more than $40 \%$ of river discharge and $\sim 26 \%$ of the sediments transported by the rivers, reducing global sediment delivery to oceans and commonly leading to coastal erosion.

Several metrics have been developed to assess the magnitude and temporal trends in alterations in river flow regimes induced by hydraulic infrastructure (Richter et al., 1996, 1997; Martínez Santa-María and Fernández Yuste, 2008; Yin et al., 2015). Additionally, extensive sediment monitoring efforts and sediment budget estimations have quantified sediment flux alterations (Surian and Cisotto, 2007; Schmidt and Wilcock, 2008; Melis, 2011; Trinity Management Council, 2014; Espa et al., 2015). Several studies have documented the hydrologic impacts of extensive dam systems, in partic- 
ular in the Alpine region over the 20th century (Botter et al., 2010; Comiti, 2012; Bocchiola and Rosso, 2014). Overall, flow regime alteration has implied significant changes in flow magnitude, frequency, timing and duration, and thermopeaking (Gore and Petts, 1989; Frutiger, 2004; Zolezzi et al., 2009, 2011). The effects of damming on sediment flux have been assessed in reaches which were directly affected (Graf, 1980; Williams and Wolman, 1984; Gaeuman et al., 2005; Petts and Gurnell, 2005; Schmidt and Wilcock, 2008; Grant, 2012), as well as in lowland gravel-bed rivers affected by cascading connected reservoirs and other human disturbances at the basin scale (Rinaldi and Simon, 1998; Surian and Rinaldi, 2003; Bilotta and Brazier, 2008; Surian et al., 2009b; Zawiejska and Wyżga, 2010; Ziliani and Surian, 2012; Scorpio et al., 2015).

It is widely acknowledged that reduced sediment flux due to dam construction or sediment supply alteration at the basin scale (e.g. due to afforestation or torrent control works) produces channel changes, namely, narrowing, incisions, reduced braiding intensity and the coarsening of bed sediment. There has been increasing attention since the 1970s on the environmental effects of large dams (Turner, 1971; Vörösmarty et al., 2003). Different river management strategies have been adopted to address dam-related impacts using structural, operational (e.g. Kondolf et al., 2014) or processbased approaches to restore water and sediment fluxes (Wohl et al., 2015a). Flow releases from dams have been regulated to reproduce aspects of natural regimes (flow and sediment), via increasing or recovering seasonal baseflow (McKinney et al., 2001; Sabaton et al., 2008), controlling the timing and recession rates of releases (Rood et al., 2003; Shafroth et al., 2010), artificial gravel augmentation or sediment bypassing (McManamay et al., 2013; Kondolf et al., 2014), flood releases (Collier, 2002; Dyer and Thoms, 2006) and experimental high-flow releases (Melis, 2011; Olden et al., 2014). In other cases, management strategies have focused directly on recovering morphological features by removing dams (Poulos et al., 2014; O'Connor et al., 2015) or by mechanically removing vegetation (Environment Canterbury Regional Council, 2015).

Environmental flow management plans are aimed at mitigating undesired channel adjustments due to dam operations. Given the costs of these programmes, decision-makers are increasingly requesting the scientific community to develop appropriate tools capable of (i) identifying and controlling the factors that cause channel alterations and (ii) assessing the effectiveness of management programmes. Environmental agencies in several countries require dam operations to respect release protocols to mitigate adverse impacts on downstream ecosystems (Schmidt and Wilcock, 2008; Olden and Naiman, 2010; Watts et al., 2011; Konrad et al., 2012). Although successful empirical experiences do exist (Souchon et al., 2008; Konrad et al., 2011), robust predictive tools and models are urgently needed to predict channel responses to dam operations and the interruption of the longitudinal river continuum (Bliesner et al., 2009; McDonald et al., 2010; Melis, 2011; Coulthard and Van De Wiel, 2013; Gaeuman, 2014).

The evolutionary trajectory of channel morphology can be assessed using conceptual (e.g. channel evolution models - CEMs, as described in Schumm et al., 1984; Simon and Hupp, 1986; Simon, 1989), empirical (Lane, 1955; Schumm, 1977; Rhoads, 1992) and numerical models, either computational-fluid-dynamic (CFD) models or reducedcomplexity models (RCMs; Larsen et al., 2014). Previous applications of RCMs on braided rivers have focused mainly on theoretical scale-independent analysis (Murray and Paola, 1994), laboratory experiments (Doeschl-Wilson and Ashmore, 2005; Doeschl et al., 2006; Nicholas, 2010) or short gravel-bed river reaches (Coulthard et al., 2002, 2007; Thomas and Nicholas, 2002; Thomas et al., 2007; Van De Wiel et al., 2007). In this study, as in Ziliani et al. (2013) and Ziliani and Surian (2016), we apply an RCM model at mesospatial (i.e. $5-50 \mathrm{~km}$ ) and mesotemporal (i.e. 10100 years) scales. In particular, the CAESAR-LISFLOOD model (Bates et al., 2010; Coulthard et al., 2013) is applied to a $7 \mathrm{~km}$ long braided reach of the Piave River (Italy), one of the most heavily and historically regulated river systems in Italy.

We applied the CAESAR-LISFLOOD model (hereafter CL) to assess the morphological effects of two flow regime management strategies. The first is characterized by yearly controlled floods with peaks capable of transporting sediments, while the second consists of less frequent highermagnitude floods (i.e. floods with 5-year recurrence intervals), released only when notable channel narrowing is observed in the evolutionary trajectory. Both strategies have been developed according to two main criteria: (i) the maximization of the flow regime re-naturalization, meaning that the duration of the controlled flood (CF) is designed to approach natural conditions as much as possible, and (ii) the feasibility of the strategy, which is verified by the fact that the cumulative volume released per year is less than the maximum volume in the reservoirs upstream from the studied reach.

This paper addresses two main issues: (i) the effectiveness of controlled floods for the geomorphic recovery of a strongly regulated braided river and (ii) the suitability and reliability of the reduced-complexity CAESAR-LISFLOOD morphodynamic model to reproduce the morphological evolution of large gravel-bed rivers at given mesoscales. In the first section of the paper, we provide a brief description of the studied river reach. The second section presents the available data, the two models used, the morphodynamic CAESARLISFLOOD model (Bates et al., 2010; Coulthard et al., 2013) and the hydrological model (Botter et al., 2007), and the criteria to design the scenario strategy. The third section presents the results in terms of (i) historical morphological river reach adjustments, (ii) flow regime alterations, (iii) the CAESAR-LISFLOOD calibration and (iv) the simulations of 
three controlled-flood release scenarios. Finally, we critically discuss the results and examine the strengths and weaknesses of CAESAR-LISFLOOD and the effectiveness of the flow management strategies under investigation.

\section{General setting of the study area}

\subsection{The Piave River basin}

The Piave River is located in northeastern Italy. It flows for about $220 \mathrm{~km}$ from the Alps to the Adriatic Sea (Fig. 1). The basin area is about $3900 \mathrm{~km}^{2}$, and its average elevation is about $1300 \mathrm{~m}$ a.s.l. (maximum elevation is $3364 \mathrm{~m}$ a.s.1.). The climate is temperate and humid, with average annual precipitation of approximately $1350 \mathrm{~mm}$. Annual rainfall varied substantially over the 20th century but without any statistically significant trends (Surian, 1999).

Like most Italian Alpine rivers (Surian and Rinaldi, 2003; Surian et al., 2009c; Comiti, 2012), the Piave River has suffered heavy human impact, which has altered the basin and river channel dynamics (Surian, 1999; Botter et al., 2010; Comiti et al., 2011; Comiti, 2012). The Piave basin experienced a rapid increase in anthropogenic exploitation in the 20th century, with the construction of a series of dams and reservoirs between the 1930s and 1960s. There are now 13 major reservoirs along the main stem and some tributaries (Botter et al., 2010). A complex regulation scheme is in place (for details see Surian, 1999; Botter et al., 2010) to maximize hydroelectric power production and provide irrigation water (Fig. 1). Flow regulation alters both flow duration and the volume of annual runoff in the river. The reservoirs and diversions along the river and its tributaries also affect sediment transport and supply.

The Piave basin has historically experienced strong changes due to land use modifications. Since the 1950s, traditional agricultural production on mountain slopes has been abandoned largely because of the development of industry and tourism, resulting in natural reforestation in the upper parts of the basin (Del Favero and Lasen, 1993). In addition to trapping by dams and reforestation, intense in-channel gravel mining has contributed to reducing sediment fluxes since the 1960s. Human pressure on river channel dynamics has also resulted from the construction of bank protection structures and torrent control works, as a result of which the river can still move laterally, although the available width for planform shifting is narrower than its natural braided belt.

\subsection{Study reach}

The studied reach is $\sim 7 \mathrm{~km}$ long (Fig. 1) and is located between Ponte nelle Alpi and Belluno (the drainage area at Belluno is $1826 \mathrm{~km}^{2}$ ). The morphology of the reach is mainly braided and wandering. The average slope is $0.47 \%$, and the median surface grain size ranges between 18 and $32 \mathrm{~mm}$ (Tomasi, 2009). The active-channel width ranges between
43 and $452 \mathrm{~m}$ and is $241 \mathrm{~m}$ on average, while the fluvial corridor width, defined by the presence of Holocene fluvial terraces (Surian, 1996), ranges between 106 and $1110 \mathrm{~m}$ and is $672 \mathrm{~m}$ on average. Previous studies (Surian, 1999; Surian et al., 2009c; Comiti et al., 2011; Picco et al., 2017) have outlined that over the last 200 years, the studied reach has undergone notable lateral adjustments (narrowing up to $66 \%$ ) but with no significant changes in channel patterns. Two phases have been identified in terms of changes in bed levels, with first a phase of moderate incision (1970 to 1990s) followed by a more recent phase (1990s to 2003-2007), during which the river has exhibited equilibrium or slight aggradation (Surian et al., 2009c; Comiti et al., 2011).

\section{Materials and methods}

\subsection{Channel morphology and the reconstruction of evolutionary trajectory}

Channel morphology was analysed to gather (i) input data for the CAESAR-LISFLOOD model, (ii) data for model calibration and (iii) evidence of the evolutionary trajectory of the studied reach. The river channel, islands, flowing channels, bank protection structures and groynes were digitized using the available aerial photos and terrain models covering the studied reach (i.e. 2003 and 2009; Table 1). The analysis employed ArcGIS 10.2. The flowing channels and bars with little or no vegetation were merged to measure channel width. The braiding index was calculated using the average number of anabranches across the river (Ashmore, 1991; Egozi and Ashmore, 2008). The historical analysis of Comiti et al. (2011), which covered the period of 1805-2006, was extended to 2009.

A lidar digital elevation model (DEM) was provided by the Autorità di Bacino delle Alpi Orientali. It was created using an airborne lidar survey in July 2003 (orthometric elevations adopted and vertical error estimate of $\pm 20 \mathrm{~cm}$ ), almost contemporary to an aerial photo used in this study (Table 1). Even though the river reach is characterized at low flow by the presence of rather small inundated areas, it was not possible to obtain bed elevation in the flowing channel areas with the standard lidar data. To obtain bed elevation, the water depth was estimated by applying the method proposed by Bertoldi et al. (2011) using the 2003 aerial photos. This is an optical remote sensing technique (Marcus, 2012) for retrieving shallow-water depth information using the colour of the pixel. Legleiter et al. (2009) demonstrated that the log transformation of the ratio of the green over the red band correlates linearly with water depth across a wide range of substrate types. The linear regression is usually calibrated by direct measurement of water depths at the time of the aerial survey. Since such data were not available, we calibrated the regression coefficients by referring to the topography of the 2003 and 2009 cross-section surveys. 

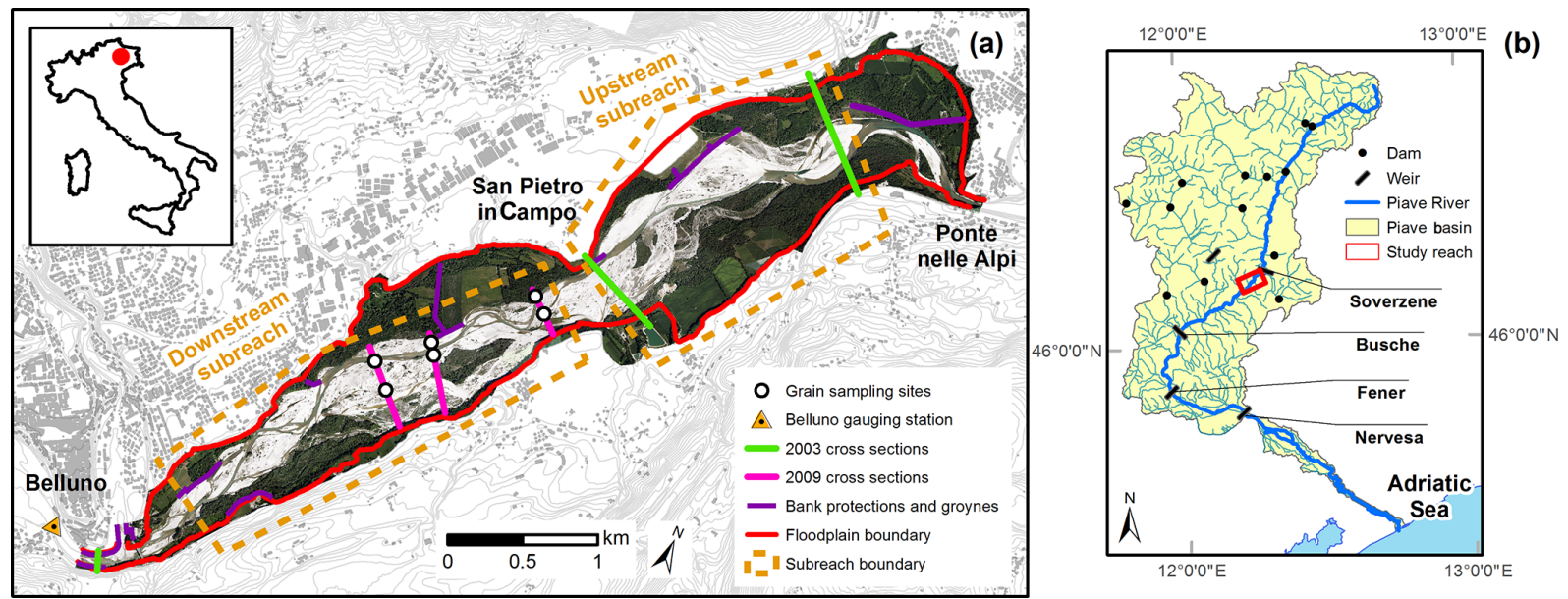

Figure 1. (a) Study reach location. (b) Water infrastructure system in the Piave basin.

Sediment grain sizes were surveyed in 2009 (Tomasi, 2009) using volumetric sampling of the surface layer (Fig. 1). A single probability density curve was extracted $\left(D_{50} \sim\right.$ $24.5 \mathrm{~mm}, D_{15} \sim 2 \mathrm{~mm}$ and $D_{84} \sim 77 \mathrm{~mm}$ ) with nine size classes, as required by the $\mathrm{C}-\mathrm{L}$ morphodynamic model.

\subsection{Analysis of the hydrologic regime of the Piave River}

There are several approaches to analyse the impact of the regulation on the natural flow regime of rivers (Richter et al., 1996, 1997; Martínez Santa-María and Fernández Yuste, 2008; Yin et al., 2015). In the case of the Piave River, although several studies have investigated the degree of alteration to its hydrological regime (Villi and Bacchi, 2001; Botter et al., 2010; Comiti et al., 2011), such an analysis has been hampered by (i) the lack of a long-term flow data series and (ii) the difficulty in distinguishing between natural and artificial components of the flow regime. In Da Canal et al. (2007) and Comiti et al. (2011), flow records derived from two gauging stations (Busche and Segusino; Fig. 1) were modified using a specific corrective factor (Villi and Bacchi, 2001) and then merged. Comiti et al. (2011) confirmed that the largest flood event at Busche (Fig. 1) occurred in 1966 and reached almost $4000 \mathrm{~m}^{3} \mathrm{~s}^{-1}$. Furthermore, their analysis showed that discharges with a recurrence interval (RI) of 2 years were not statistically different if calculated separately for pre- and post-regulation periods (1954 was used as the separation date between the periods). However, the peak discharges of the more frequent events ( $\mathrm{RI} \leq 1.5$ years) decreased after 1954 . Picco et al. (2017) reported similar outcomes.

Botter et al. (2010) offered a more detailed analysis of the impact of regulation on river regimes with the application of physically based modelling to assess alterations in the streamflow regime observed in various cross sections of the drainage network downstream from dams and weirs. The authors applied an analytical stochastic model (Botter et al., 2007) to characterize the streamflow probability density function (PDF) by means of climate, soil and vegetation parameters. After applying a preliminary model to smaller unregulated sub-catchments (that allowed for properly verifying the capability of the model to reproduce the natural streamflow regime locally), the author applied the model to several regulated sections of the Piave River, including Soverzene (about $5 \mathrm{~km}$ upstream from Ponte nelle Alpi; Fig. 1), in order to evaluate the natural flow regime in regulated cross sections and, based on the difference, the effect of regulation on the statistical hydrographic features. The approach conceptualizes the dynamics of daily streamflow as a sequence of peaks in response to rainfall and decays in between these jumps. These jump-decay dynamics are then linked to a catchment-scale soil-water balance in which the input is represented by stochastic daily rainfall. In this setting, flow-producing rainfall events (that lead to streamflow jumps) result from the censoring operated by catchment soils on daily rainfall, which are modelled as a marked Poisson process with mean depth $\alpha$ and mean frequency $\lambda$. The parameter $\alpha$ identifies the average intensity of daily rainfall events, while $\lambda$ is the frequency of flow-producing events, which is less than the underlying precipitation frequency because of the effect of soil moisture dynamics and evapotranspiration. As a consequence, several climate variables (such as rainfall attributes), as well as soil and vegetation properties, are embedded in $\lambda$. In this framework, streamflow recessions between flow pulses are assumed to be exponential, with a mean rate equal to $k$, which defines the inverse of the timescale of the hydrological response (i.e. the mean water retention time in the upstream catchment). Under these assumptions, it can be shown that the steady-state PDF of the specific daily discharge (discharge per unit catchment area) is a gamma distribution with shape parameter $\lambda / k$ and scale parameter $\alpha k$. The model is applied at the seasonal timescale, and then the annual PDF is calculated as the average of the four seasonal distributions. The presence of snow dynamics 
in winter in the uppermost regions of the catchment is accounted for by reducing the size of the active contributing catchment and increasing the recession rates as described by Schaefli et al. (2013), with an elevation threshold of about $1900 \mathrm{~m}$ a.s.l. In spring, a base flow value is added to the modelled streamflow distribution, which corresponds to a rigid rightward shift of the PDF. The probability distribution of natural daily streamflows estimated by the model is then compared to the PDF of the observed daily flows to assess the extent of the impact of regulation in the lower reaches of the Piave River and to obtain guidelines for devising meaningful flow regime management strategies. In particular, the daily streamflow series used in this study was recorded from 1995 to 2009 at the Belluno gauging station located at the downstream section of the studied reach (Fig. 1). The highest flood event peaks observed in the reference periods $(1996,2000$ and 2002) were checked and modified, combining data from Belluno and discharge measurements at the Soverzene weir (Braidot, 2003).

\subsection{The CAESAR-LISFLOOD model}

The application of hydro-morphodynamic physically based numerical models (generally known as computational-fluiddynamic models - CFDs) over the last 20 years has mainly been focused on idealized channel configurations at the laboratory scale (Wu et al., 2000; Defina, 2003; Rüther and Olsen, 2005; Abad et al., 2008) or the morphological dynamics of natural channels over short time periods (Darby et al., 2002; Chen and Duan, 2008; Li et al., 2008; Wang et al., 2008; Zhou et al., 2009). The limited range of application of these models reflects unresolved issues of data availability and high computational demands (Escauriaza et al., 2017). Only a few recent works (i.e. Nicholas, 2013a; Williams et al., 2016) have shown that CFD models can be applied at larger spatial and temporal scales. This limitation has led to the development of alternative two-dimensional models that are commonly referred to as cellular automata (Murray, 2007), cellular models (Murray and Paola, 1994; Coulthard et al., 2002, 2007; Thomas and Nicholas, 2002; Parsons and Fonstad, 2007; Van De Wiel et al., 2007), exploratory models or reduced-complexity models (RCMs; Murray, 2007; Nicholas et al., 2006, 2012). These models have a common solution to the problem, which is the adoption of simplified hydrodynamic and sediment transport equations derived by abstractions of the governing physics.

A major advantage of RCMs is their computational efficiency, which allows for simulating river evolution over historic and Holocene timescales (e.g. Coulthard et al., 2002, 2005; Nicholas and Quine, 2007; Thomas et al., 2007; Van De Wiel et al., 2007). However, the physical realism of these models has received relatively little attention (Nicholas, 2009, 2013b; Ziliani et al., 2013), and there have been only a few studies that deal with the high sensitivity of these models to the grid resolution of the computational domain 
(Doeschl-Wilson and Ashmore, 2005; Doeschl et al., 2006; Nicholas and Quine, 2007). Despite the progress made in several works (Nicholas, 2009, 2013a), there are still few applications to natural rivers characterized by complex channel morphology (Ziliani et al., 2013; Ziliani and Surian, 2016).

In this study, we applied the CAESAR-LISFLOOD model (1.2 version, reach mode; see the Supplement for details about the model; Coulthard et al., 2013), which is an integration of the LISFLOOD-FP (Bates et al., 2010) and CAESAR (Coulthard et al., 2007; Van De Wiel et al., 2007) models. The C-L model links the hydraulics of the former with the erosion and deposition components of the latter. LISFLOOD-FP is a one-dimensional inertial model derived from the full shallow-water equations applied in the $x$ and $y$ directions to simulate two-dimensional flow over a rasterized spatial domain (Bates et al., 2010). LISFLOOD-FP has been successfully tested to simulate hydraulics in shallow-water environments affected by strongly unidirectional flow (Bates et al., 2010; Neal et al., 2012; Coulthard and Van De Wiel, 2013; Lewis et al., 2013; Skinner et al., 2015; Wong et al., 2015) and for flood simulations characterized by rapid wetting and drying condition (Bates et al., 2010). The CAESAR model (Coulthard et al., 2007; Van De Wiel et al., 2007; Ziliani et al., 2013) represents the morphodynamic component of the integrated C-L model. Ziliani et al. (2013) submitted CAESAR to a rigorous and objective performance evaluation and found that CAESAR (i) can be a very powerful tool for modelling spatial and temporal scales that are not well supported by two-dimensional to three-dimensional morphodynamic CFD models, (ii) can be very useful for setting "whatif scenario" strategies over mesospatial and mesotemporal scales, and (iii) provides reliable bedload sediment budget estimations. From a morphological point of view, Ziliani et al. (2013) showed that CAESAR can reproduce the average change in channel width but performs poorly in reproducing braided in-channel pattern dynamics and the typical topographic complexity of a braided river at low-water stages (e.g. braiding intensity). LISFLOOD-FP and CAESAR have been efficiently integrated and tested in the new CAESARLISFLOOD model (see Coulthard et al., 2013, for details). The C-L model has been applied at reach (Feeney et al., 2020) and catchment scales (Coulthard and Van De Wiel, 2017), and Skinner et al. (2018) assessed the sensitivity of the model. Feeney et al. (2020) used the model to reconstruct geomorphic changes for 10 alluvial reaches in northern England and found that the model accurately reproduces channel and floodplain dynamics at mesotemporal scales.

\subsection{Morphodynamic-model performance assessment}

Several works (Darby and Van De Wiel, 2003; Hoey et al., 2003; Wilcock and Iverson, 2003) have emphasized the challenge of the proper calibration of process-based models in fluvial geomorphology due to the increasing uncertainty proportional to the increased complexity of the modelled pro-

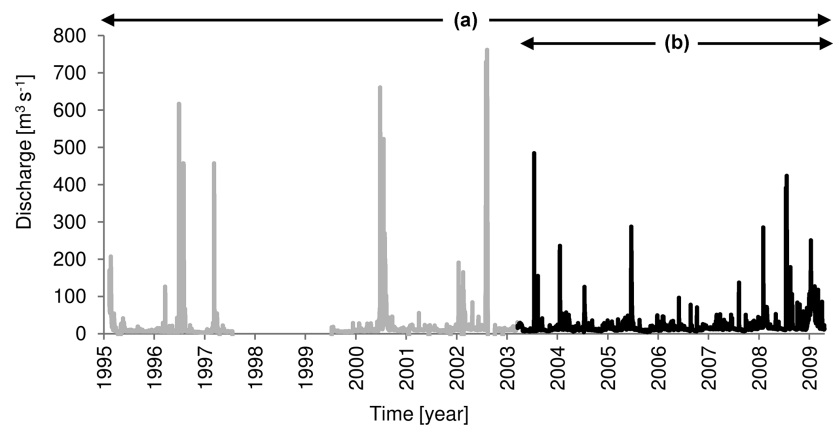

Figure 2. (a) 1 June 1995-31 December 2009 hourly discharge series used for the scenarios runs; (b) hourly discharge series measured at Belluno gauge station used for the calibration run (5 July 2003-5 August 2009).

cess and the number of parameters to be estimated (Formann et al., 2007; Papanicolaou et al., 2008). Despite this intrinsic complexity, it is crucial to understand the limitations and performance of RCMs (Aronica et al., 2002; Hall et al., 2005; Lane, 2006), adopting methods that (i) can include all the limitations inherent in calibrating this type of model and (ii) are mainly based on field and remote sensing data (Nicholas, 2010). There are currently no standard international methods for the calibration and validation of fluvial morphodynamic models (Mosselman, 2012), and those previously proposed are typically designed for hydrodynamic CFD models (ASME, 1993; Lane et al., 2005). It must also be kept in mind that a calibrated RCM model can be simply empirically adequate (Van Fraassen, 1980) and its validation is simply a confirmation (Oreskes et al., 1994) that cannot be considered conclusive (Haff, 1996; Lane et al., 2005; Murray, 2007). Calibration of the C-L model was specifically addressed by Feeney et al. (2020), who pointed out the need for reach-specific calibration to increase model performance.

Given all of the above, the C-L was calibrated with reference to the 5 July 2003-5 August 2009 period (Fig. 2) by comparing the model output (i.e. morphological features such as channel boundaries, islands and wet-channel positions) to the digitized channel morphology based on the 2009 aerial photos (see the Supplement for a detailed description of the model calibration). The hourly discharge series was used as an upstream flow boundary condition. At the downstream end of the reach, a constant energy slope was fixed at $0.0047 \mathrm{~m} \mathrm{~m}^{-1}$, equal to the local bed slope. The initial bed sediment grain size was set according to Tomasi (2009). Nine grain size classes were used to define the size distribution, which was considered homogeneous throughout the reach. Due to the lack of field estimates of bedload at the upstream end of the reach, we assumed the sediment recirculation option available in C-L (i.e. sediment input equals the output at the downstream end of the reach). The model factor termed sediment proportion recirculated (SPR) was assumed to be 1 , which assumes that sed- 
iment load upstream is the same as it is downstream (i.e. sediment transport equilibrium condition). Vegetated areas (i.e. islands and recent and old terraces covered by arboreal vegetation) and channelization structures (i.e. bank protection structures, groynes and levees) were digitized combining the 2003 aerial photos and the lidar digital surface model (DSM; $2 \mathrm{~m}$ grid dimension; Table 1). The vegetation cover was used as the initial modelled vegetation condition (maturity fixed at 1). The initial bed elevation was established using a $10 \mathrm{~m}$ DEM cell obtained by resampling the 2003 lidar DEM (bilinear interpolation; original cell dimension of $2 \times 2 \mathrm{~m}$ ). The $10 \mathrm{~m}$ cell dimension was chosen to ensure a reasonable computational time for long-term scenario runs and for a spatial resolution higher than previous works (e.g. $25 \mathrm{~m}$ in Ziliani et al., 2013). The DEM was corrected in the wetted areas (about $8 \%$ of the total spatial domain) through the application of the method proposed in Bertoldi et al. (2011) and forced to be nonerodible in the areas occupied by both channelization structures still effective in 2003 and undamaged structures built since the 19 th century.

\subsection{Flow regime management strategies}

Water management of historically regulated rivers may be oriented to restoring the flow regime to close to that before impact, typically aimed at reactivating physical processes linked to specific components of the flow regime (Wohl, 2011). Nevertheless, existing priorities in water resource use often limit the feasibility and effectiveness of flow regime re-naturalization strategies, and in most cases the strategy is merely reduced to the definition of a minimum volume of water released for partial restoration goals. Olden et al. (2014) systematically reviewed flood experiments to evaluate globally the success of this practice in flow regime management. They considered 113 flood experiments in 20 countries and found that only $11 \%$ of the case studies were aimed directly at morphological effects, while around $80 \%$ involved only low-magnitude flow events. Most experimental flow releases are focussed on biological variables (primarily fish), aquatic organisms (Konrad et al., 2011) and re-establishing vegetation (Shafroth et al., 2010), rather than on abiotic factors (e.g. channel morphology; Wohl et al., 2015b). What are termed "environmental flows" and "Green Hydro" are widely accepted concepts that refer mainly to the quantity, timing, duration, frequency and quality of water flow releases, as required to sustain freshwater, estuarine and near-shore ecosystems according to social interests (Acreman and Ferguson, 2010; Rivaes et al., 2017).

Thus, there have been few examples of flow regime recovery strategies with primarily morphological goals. The Colorado River below the Glen Canyon Dam represents the most important exception. Several controlled floods (i.e. five high flood experiments) were released between 1996 and 2013 to maintain and rehabilitate sandbars that occur in lateral flow separation eddies (Schmidt and Wilcock, 2008; Melis, 2011;
Mueller et al., 2014). The Trinity River (California, USA) represents another excellent case study, in which morphological goals were among the multiple flow objectives (Trinity Management Council, 2014). Nevertheless, with the exception of the lower Waitaki River in New Zealand, there are no examples of morphological recovery or conservation of braided rivers, and no controlled floods have been used on the Waitaki (Hicks et al., 2003, 2006; Environment Canterbury Regional Council, 2015).

Provoking controlled floods or removing vegetation are costly and can preclude other actions, so it is worthwhile to assess these strategies and consider the morphological effects of different channel-forming discharges (Surian et al., 2009a). Rathburn et al. (2009) stressed that flow releases from dams must exceed a series of thresholds to be morphologically effective. Four discharge thresholds of increasing intensity should be identified in a morphological recovery and conservation plan, each capable of activating a specific morphological process: (i) the mobilization of interstitial sediment essential for hyporheic exchange maintenance, (ii) the mobilization of the streambed to maintain natural bedforms, (iii) the inundation of overbank units (i.e. berms, floodplains and terraces) to confine encroachment by xeric plants, and (iv) the lateral channel mobility that can remove senescent woody vegetation and create opportunities for seedlings to germinate and mature. Once each threshold discharge value or range is quantified, the flow duration can be tuned within the limits imposed by the available flow, using the natural flow regime as a reference.

The flow regime management scenarios used in this work were defined in reference to three flood threshold levels that partially match those proposed by Rathburn et al. (2009): (i) full in-channel transport discharge assumed to be capable of mobilizing interstitial sediment, (ii) the bankfull discharge capable of maintaining natural bedforms and (iii) overbank discharge capable of affecting the main lateral units by inundation. A field study conducted in the reach using painted sediments similar to those used in Mao and Surian (2010) and Mao et al. (2017) resulted in an estimate of the first reference threshold at $80 \mathrm{~m}^{3} \mathrm{~s}^{-1}(\mathrm{RI}<1$ year; full transport discharge capable of mobilizing sediments, irrespective of their size). The bankfull discharge was estimated using the calibrated C-L model and was approximated to the discharge filling the active channels and bars without overflowing onto the oldest island assumed to be morphologically equivalent to the recent fluvial terraces (Williams, 1978; Pickup and Rieger, 1979; Surian et al., 2009a). The bankfull discharge is about $500 \mathrm{~m}^{3} \mathrm{~s}^{-1}$ and corresponds to a 2.5-year RI, which is consistent with other references in the literature (Leopold, 1994). Only $>1000 \mathrm{~m}^{3} \mathrm{~s}^{-1}$ floods were identified as capable of completely inundating the oldest island and overflowing locally into recent fluvial terraces.

Four simulation scenarios were considered, all covering the same 25-year period (2009-2034; Table 2). The first scenario (i.e. baseline scenario, SC1) is the current con- 
dition, characterized by a strongly altered flow regime. In this case, the discharge series for 1995-2009 (hourly data at the Belluno gauge station) was repeated twice. Both scenarios 2 (SC2) and 3 (SC3) used a flow regime strategy characterized by one CF per year. The yearly CF in SC2 had a constant value of $135 \mathrm{~m}^{3} \mathrm{~s}^{-1}$ (RI $\sim 1.08$ years), which was calculated as the average of the maximum annual floods observed in 1995-2009. This was higher than the reference threshold discharge, i.e. the full in-channel transport discharge $\left(80 \mathrm{~m}^{3} \mathrm{~s}^{-1}\right)$. The yearly CF values for SC3 were randomly selected above the threshold discharge using the natural streamflow PDF estimated by the model (minimum value of $80 \mathrm{~m}^{3} \mathrm{~s}^{-1}$; maximum value of $276 \mathrm{~m}^{3} \mathrm{~s}^{-1}$; RI of $\sim 1.4$ years). In this case, the average of all the $\mathrm{CF}$ values is equal to the yearly $\mathrm{CF}$ discharge for $\mathrm{SC} 2$, assuming values included in the [80-276] $\mathrm{m}^{3} \mathrm{~s}^{-1}$ range. All the CFs had a fixed duration of $5 \mathrm{~d}$, according to the re-naturalization maximization criteria. In SC2 and SC3, the cumulative likelihood to occur associated with the released peaks increased from 0.025 (actual observed altered regime) to 0.04 , with the natural reference value being 0.14 . Scenario 4 (SC4) was planned to represent a different management strategy, consisting of larger CFs released by dams (constant value for $1 \mathrm{~d}$ ) only following the observation of notable channel narrowing. Specifically, we assumed $200 \mathrm{~m}$ to be a threshold for average channel width, considering the evolutionary trajectory over the last 200 years and, in particular, the most intense narrowing that took place in the early 1990s (Fig. 3). Based on channel width measurements taken by a 1-year step in the SC4 simulation, only two CFs were released, one in 2020 and the other in 2032. The released discharge was fixed at $600 \mathrm{~m}^{3} \mathrm{~s}^{-1}$ (RI of 5 years), ranging between the second and the third reference threshold discharges discussed above so that it would undoubtedly be capable of maintaining in-channel bedform dynamics while completely avoiding any hydraulic risks and damages in the overbank units (i.e. recent terraces), locally occupied by secondary roads and cultivated fields.

All the CFs were released in November, while overlapping floods were avoided. All the scenarios made use of the same model setting, which was obtained in the calibration phase, using the 2009 calibration output data in a raster format as the initial boundary conditions (i.e. bed elevation, nonerodible hydraulic structures, vegetation cover and grain size distribution). As reported in Table 2, all the scenarios required the release of a cumulative volume per year (i.e. per flood) which was considerably less than the maximum volume in the reservoirs upstream from the studied reach $\left(90.8 \mathrm{M} \mathrm{m}^{3}\right)$. $\mathrm{SC} 2$ and $\mathrm{SC} 3$ required similar volumes of about $58 \mathrm{M} \mathrm{m}^{3}$ of water, or around $1.45 \times 10^{3} \mathrm{M} \mathrm{m}^{3}$ over the entire scenarios period. SC4 represents the last expensive scenario because it needed $51.8 \mathrm{M} \mathrm{m}^{3}$ per year and $104 \mathrm{M} \mathrm{m}^{3}$ globally, 1 order of magnitude less than in the other scenarios.

\section{Results}

\subsection{Evolutionary trajectory of channel morphology}

Using the available dataset on morphological changes of the Piave River (Comiti et al., 2011), we reconstructed and updated the channel adjustments to 2009. The analysis focused on two sub-reaches, upstream and downstream from San Pietro in Campo, respectively, where the river is naturally more confined (Fig. 1). The reach was divided into two sub-reaches to better describe the morphological adjustments over the 1800-2009 period. The trends in average width in the sub-reaches are similar and characterized by four main adjustment phases (Fig. 3): (i) a first period (during the 19th century and the first half of the 20th century) dominated by a braided pattern, with channel width equal to about $80 \%$ of the alluvial plain width, negligible morphological changes and the absence of a dominant process (i.e. channel widening or narrowing); (ii) a second phase of adjustment with channel narrowing of about $60 \%$ from the 1950 s to the early 1990 s (the channel width of the entire reach was 370 in 1960 and 247 in 1991), interrupted by a large flood event in 1966 (RI of $\sim 200$ years; Comiti et al., 2011), which caused temporary widespread channel expansion; (iii) a phase of channel widening during the 1990s (the channel width of the entire reach was $342 \mathrm{~m}$ in 1999), mainly related to the 1993 flood event, characterized by a 12-year RI (Comiti et al., 2011); and (iv) the most recent adjustment phase characterized by channel narrowing. Focusing on the last 20-25 years following the 2002 flood, the river entered a new phase (IV in Fig. 3) characterized by narrowing: channel width in 2009 (i.e. $241 \mathrm{~m}$ ) was the lowest observed in the studied reach over the last 200 years. While widening during phase III was likely due to the termination of in-channel gravel mining (Comiti et al., 2011), the most recent narrowing phase (phase IV) was likely due to the absence of major floods (see also Fig. 2).

\subsection{Flow regime alterations}

A comparison of the frequency distribution of observed daily streamflows at the Belluno cross section and the model-based estimate of streamflow PDF under unregulated conditions (Fig. 4) shows the significant impact of regulation in the lower reaches of the Piave River. The mean and the mode of the streamflow distribution are significantly reduced by anthropogenic exploitation of water resources (i.e. bypass flows and diversions). Accordingly, the exceedance probability of moderate-to-high flows is significantly reduced under current regulated conditions. In particular, the probability to observe discharges larger than $80 \mathrm{~m}^{3} \mathrm{~s}^{-1}$ is reduced by about 1 order of magnitude (i.e. from 0.14 to 0.025 ). Such results are crucial for setting the flow regime management scenario, since (i) they show that a strategy aimed at improving the current flow regime is needed and (ii) this strategy should compen- 

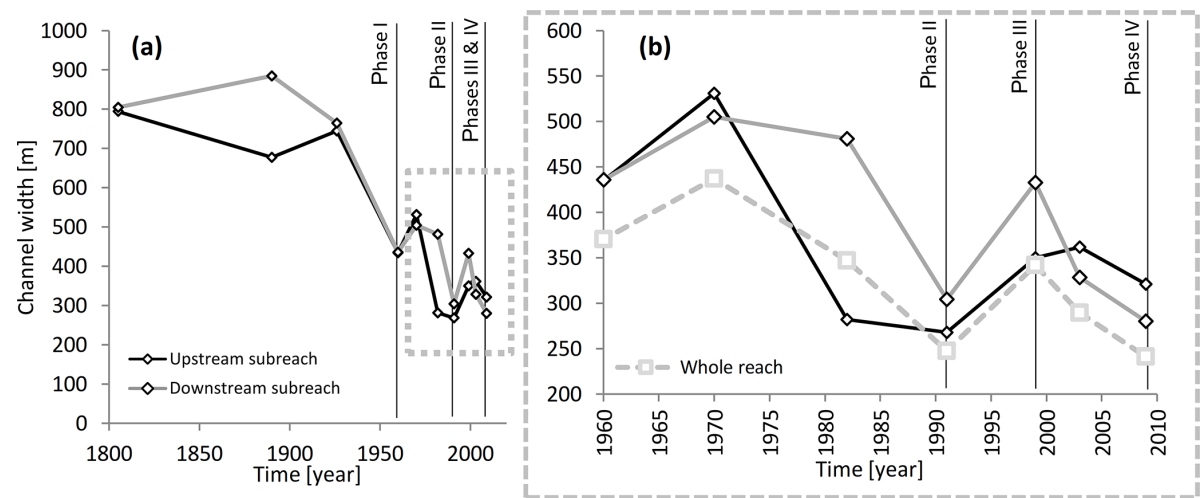

Figure 3. (a) Changes in channel width over the period of 1805-2009; (b) changes in channel width over the period of 1960-2009.

Table 2. Main hydrological characteristics of the four scenarios.

\begin{tabular}{|c|c|c|c|c|c|c|c|}
\hline Scenario & $\begin{array}{l}\text { Controlled-flood } \\
\text { release frequency }\end{array}$ & $\begin{array}{l}\text { Maximum } \\
\text { controlled-flood } \\
\text { peaks }\left(\mathrm{m}^{3} \mathrm{~s}^{-1}\right)\end{array}$ & $\begin{array}{l}\text { Controlled- } \\
\text { flood peaks } \\
\text { range }\left(\mathrm{m}^{3} \mathrm{~s}^{-1}\right)\end{array}$ & $\begin{array}{r}\text { Recurrence } \\
\text { interval } \\
\text { maximum } \\
\text { controlled } \\
\text { flood (year) }\end{array}$ & $\begin{array}{l}\text { Controlled- } \\
\text { flood } \\
\text { duration } \\
\text { (d) }\end{array}$ & $\begin{array}{r}\text { Cumulative } \\
\text { volume } \\
\text { released } \\
\text { per flood } \\
\left(\mathrm{Mm}^{3}\right)\end{array}$ & $\begin{array}{r}\text { Cumulative } \\
\text { volume } \\
\text { released } \\
\text { per scenario } \\
\left(\mathrm{Mm}^{3}\right)\end{array}$ \\
\hline $\begin{array}{l}\text { SC1 } \\
\text { (baseline } \\
\text { scenario) }\end{array}$ & No releases & No releases & No releases & - & - & 0 & 0 \\
\hline $\mathrm{SC} 2$ & One per year & 135 & Constant & 1.08 & 5 & 58.32 & $1.46 \times 10^{3}$ \\
\hline $\mathrm{SC} 3$ & One per year & 276 & [80-276] & 1.4 & 5 & 58.18 & $1.45 \times 10^{3}$ \\
\hline $\mathrm{SC} 4$ & $\begin{array}{l}\text { In case of average } \\
\text { channel width } \\
\text { narrowing under } \\
200 \mathrm{~m} \text { (twice in } \\
34 \text { years) }\end{array}$ & 600 & Constant & 5 & 1 & 51.84 & $1.04 \times 10^{2}$ \\
\hline
\end{tabular}

sate the expected low morphological dynamism of the river caused by the decreased occurrence of discharges capable of mobilizing sediments and producing significant morphological changes in the studied reach.

It is worth noting that the hydrological model underestimates the frequency of the highest flows (i.e. discharges of more than $300 \mathrm{~m}^{3} \mathrm{~s}^{-1}$ ) because all the non-linearities of the hydrological response (e.g. the presence of different flow components such as surface runoff) are neglected in this version of the model (Basso et al., 2015). As a consequence, the probability associated with the highest flows in regulated conditions is greater than the corresponding value estimated by the stochastic model for the natural setting. However, this limitation of the model does not have any significant consequences for the analysis carried out in this paper, provided that the frequency of such high flows is relatively low.

\subsection{Calibration of the morphodynamic model}

The results of Ziliani et al. (2013) and Coulthard et al. (2013) were used as a reference to calibrate the $\mathrm{C}$ - $\mathrm{L}$ model. According to the results of the sensitivity analysis in Ziliani et al. (2013), the lateral erosion rate and maximum erosion limit were the most sensitive factors that required accurate tuning. The other factors (see Table 3), including the main new parameters introduced in the $\mathrm{C}-\mathrm{L}$ version, were tuned manually by trial and error (75 runs in total). Following the performance evaluation techniques used by Ziliani et al. (2013), the calibration was based on performance indices developed specifically for data available in a raster format (Bates and De Roo, 2000; Horritt and Bates, 2001). The performance indices reported in Table 4 were calculated for all the calibration runs at the end of the simulation (2009), with these being (i) the vegetation performance index $\left(F_{\text {veg }}\right)$, (ii) the wet-area performance index $\left(F_{\text {wet }}\right)$ and (iii) the activechannel performance index $\left(F_{\mathrm{c}}\right)$. In addition, several plani- 


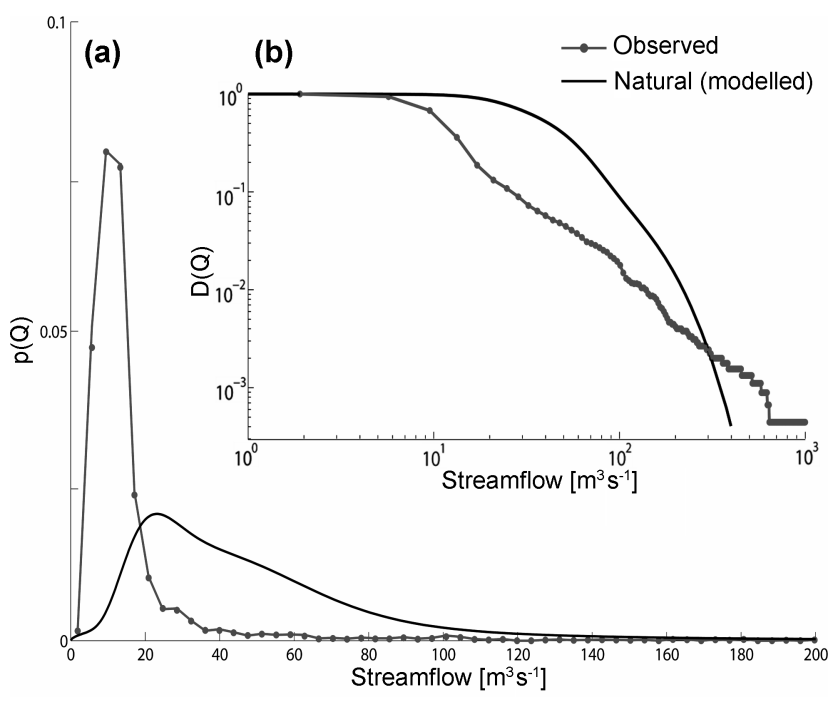

Figure 4. Effect of the anthropogenic regulations in the Piave River at the Belluno cross section. Comparison between the PDF $p(Q)$ (a) and the cumulative distribution $D(Q)$ (b) of observed streamflow in the period of 1995-2009 and the natural streamflow PDF and $D(Q)$ predicted by the model developed by Botter et al. (2010).

metric features were calculated, including the (i) average active-channel width, (ii) equivalent wet-area width $\left(L_{\mathrm{W}}\right)$ and (iii) mean braiding index (Egozi and Ashmore, 2008). The results (see Table 4 and Figs. 5, S3 and S4) show a very good performance (performance class as defined in Henriksen et al., 2003; Allen et al., 2007) for both the vegetation cover $\left(\mathrm{F}_{v e g} 69.7 \%\right)$ and the active-channel area $\left(F_{\mathrm{c}} 54.2 \%\right)$. Output values of the active-channel width and braiding index confirmed these results. The difference between real and modelled 2009 active-channel width $(6 \mathrm{~m})$ is less than the input DEM cell size $(10 \mathrm{~m})$, and the modelled braiding index value (1.71) is very close to the real value (1.69). The model only performed poorly in reproducing the flowing channel position $\left(F_{\mathrm{W}}\right.$ of $\left.15.7 \%\right)$, which partially confirms the results of Ziliani et al. (2013).

We estimated mean annual bedload sediment yield at the downstream end of the reach and along the entire reach to integrate morphological performance evaluations. Average modelled bedload sediment yield in the 2003-2009 period was around $21.5 \times 10^{3} \mathrm{~m}^{3} \mathrm{yr}^{-1}$. Modelled yield varies significantly along the reach (up to $30 \%$ ), with higher yearly values in the sub-reach upstream of San Pietro in Campo. Maximum and minimum annual values differ significantly. The 2006 minimum is about $260 \mathrm{~m}^{3} \mathrm{yr}^{-1}$ versus the 2008 maximum of about $53.3 \times 10^{3} \mathrm{~m}^{3} \mathrm{yr}^{-1}$. These sediment transport values agree with estimates for gravel-bed rivers with similar characteristics to those of the Piave River reach (Martin and Church, 1995; Ham and Church, 2000; Nicholas, 2000; Liebault et al., 2008; Ziliani et al., 2013; Mao et al., 2017).

\subsection{Channel response to flow regime management strategies: scenario results}

The channel adjustments induced by the different scenarios were assessed by comparing active-channel width and braiding intensity (BI) in each year (in February) using the same techniques adopted in the calibration phase (Fig. 6). The channel width in SC2, SC3 and SC4 was almost always greater than in SC1 (the baseline scenario). The average channel widening in SC2 and SC4 was similar throughout the scenarios, being approximately $6.4 \%(\sim 14 \mathrm{~m})$, while at the end of the scenarios (2034), widening was about $9 \%(\sim 25 \mathrm{~m})$ and $13.5 \%(\sim 38 \mathrm{~m})$ in SC2 and SC4, respectively. SC3 induced slightly less widening, about $5.4 \%$, throughout the period, and $8.6 \%(\sim 24 \mathrm{~m})$ at the end of the simulated period. The maximum annual widening was observed in SC4 ( 120 $\mathrm{m}$ in 2033$)$, followed by SC3 $(\sim 77 \mathrm{~m}$ in 2020) and SC2 ( $43 \mathrm{~m}$ in 2032; Fig. 7).

Results suggest that the CFs scenarios (SC2, SC3 and $\mathrm{SC} 4)$ and the baseline scenario (SC1) provide similar longterm morphological trajectories characterized by alternate phases of widening and narrowing and notable changes in active-channel width (width varies between 150 and $360 \mathrm{~m}$ ). Figure 7 shows that channel width oscillations take place over a period of 6 to 7 years and have an amplitude of $160 \mathrm{~m}$ in response to the alternation of periods characterized by floods of different magnitudes in the 2011-2015 and 20222028 periods, during which seven floods $>400 \mathrm{~m}^{3} \mathrm{~s}^{-1}$ (RI of $\sim 1.9$ years) occur, and the channel width follows a quasisteady trend and is greater than $300 \mathrm{~m}$. Instead, channel width decreased during periods (2017-2021 and 2029-2031) affected by lower-magnitude floods (maximum peak value of $\left.200 \mathrm{~m}^{3} \mathrm{~s}^{-1}\right)$. SC1 had a slightly decreasing trend over the entire 25 years (Fig. 7). Channel width has quasi-zero slopes in the CF scenarios, even if the channel width at the end of the simulation is about $[8.6 \%-13.5 \%]$ more than in the baseline scenario.

The braiding indices of SC2, SC3 and SC4 were similar to or lower than that of SC1. SC4 was the most similar scenario to that of $\mathrm{SC} 1$, with an average $\mathrm{BI}$ in-time value of 2.78 , which was slightly lower than that of SC1 $(-1.5 \%)$. Differences in $\mathrm{BI}$ were higher in $\mathrm{SC} 2$ than in $\mathrm{SC} 1(-7.3 \%$; BI value of 0.21 ; Fig. 7), although these differences were small. The behaviour of braiding intensity was different from channel width in that there was one period (2009 to 2023) with no clear oscillations and a clearly increasing trend, followed by a decreasing or quasi-steady (SC1) period until the end of the simulation. There is a non-linear correlation between BI and flooding series magnitude or the CFs. In particular, $\mathrm{SC} 1$ is the only scenario that did not show an inverse trend after 2023, while the SC2 scenario anomalously had a consistently lower BI value steadily lower the other CF scenarios, while SC3 and SC4 had very similar BI values. 


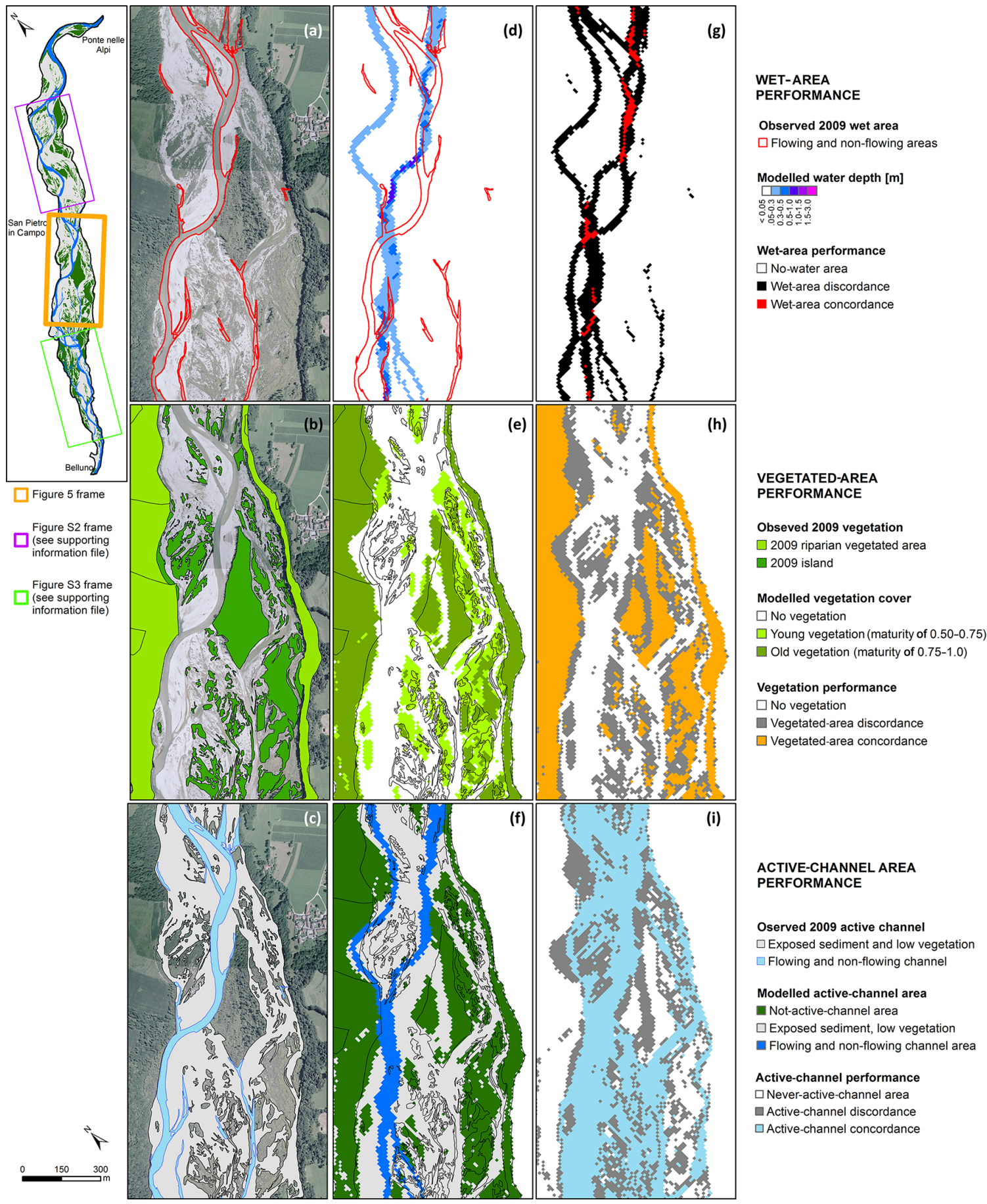

Figure 5. Model performance assessment at the end of the calibration runs (mid frame; see the Supplement for the others frames): (a) wet area, (b) vegetated area and (c) active channel digitalized using 5 August 2009 aerial photos; (d) overlay between modelled and observed flowing channel; (e) overlay between modelled and vegetated area; (f) overlay between modelled and observed active channel; (g) wet-area performance index calculation; (h) vegetated-area performance index calculation; and (i) active-channel performance index calculation. 


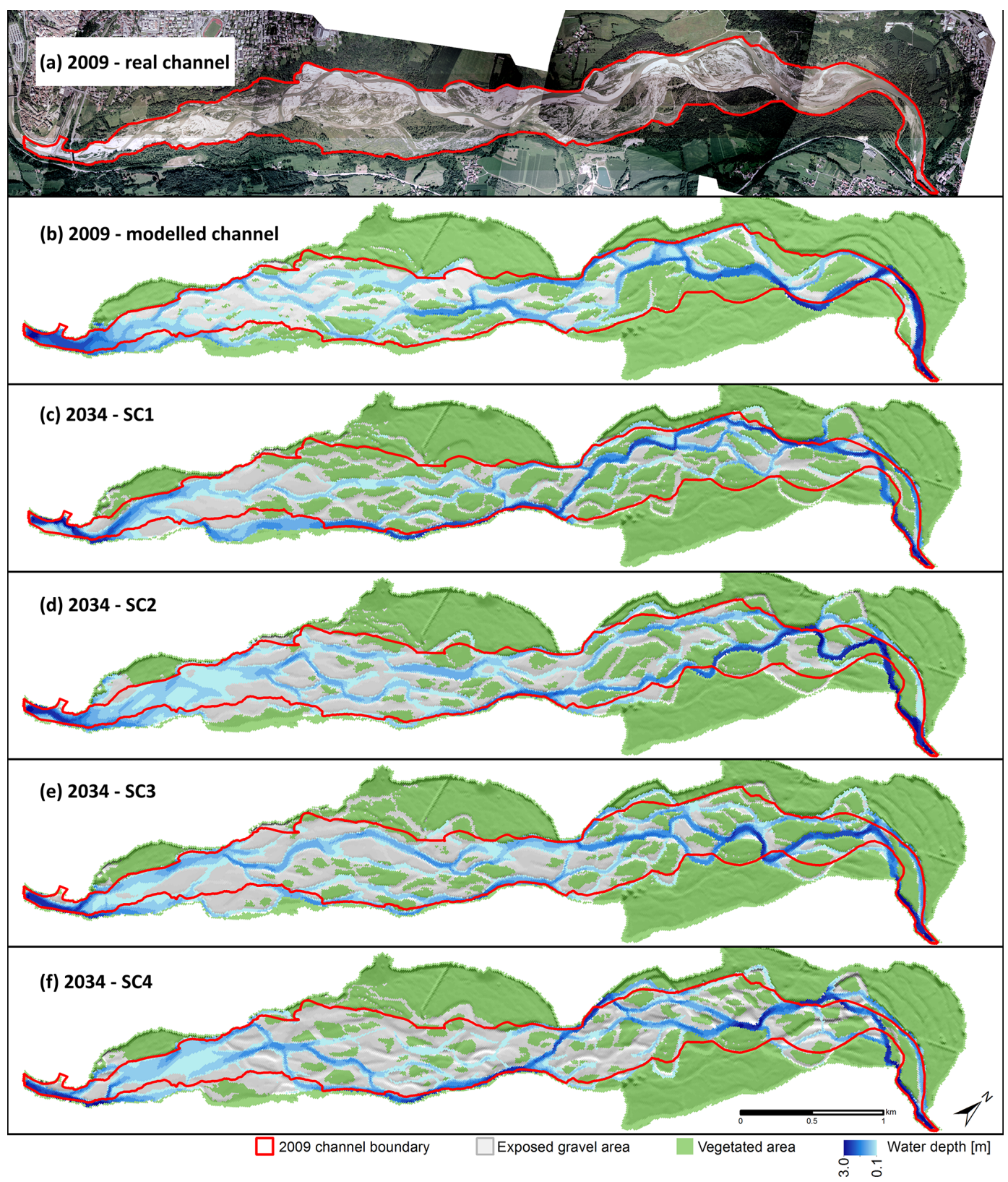

Figure 6. (a) 2009 real channel, (b) 2009 modelled channel used as starting point for the scenario runs; (c-f) results of scenarios 1-4 at the end of the runs (2034).

\section{Discussion}

\subsection{Geomorphic effectiveness of controlled floods}

Several insights can be obtained from comparing future scenarios to the historical evolutionary trajectory (Fig. 3), despite the evident mismatch between the temporal frequency of the past and future channel width series (one value every 16.5 years in the $1805-1970$ period and every 6.5 years in the 1970-2009 period; yearly values for the future series). It can be observed that (i) the maximum channel widths reached in all four future scenarios (in the periods of 2015-2016 and 2028-2029) are close to the width in 1999; (ii) the minimum widths achieved in all future scenarios (2020 and 2032) are less than $185 \mathrm{~m}$ (with the exception of the first minimum in scenario 3) and are significantly lower than the historical minimum observed in 2009 (241 m); (iii) despite a low confidence level, we can state that the trajectory between 1991 and 2009 (phase III and IV described in Sect. 4.1) follows an oscillating evolution with half of the frequency of the oscillation modelled between 2009 and 2034; and (iv) there is a good correlation between the variation of channel width 

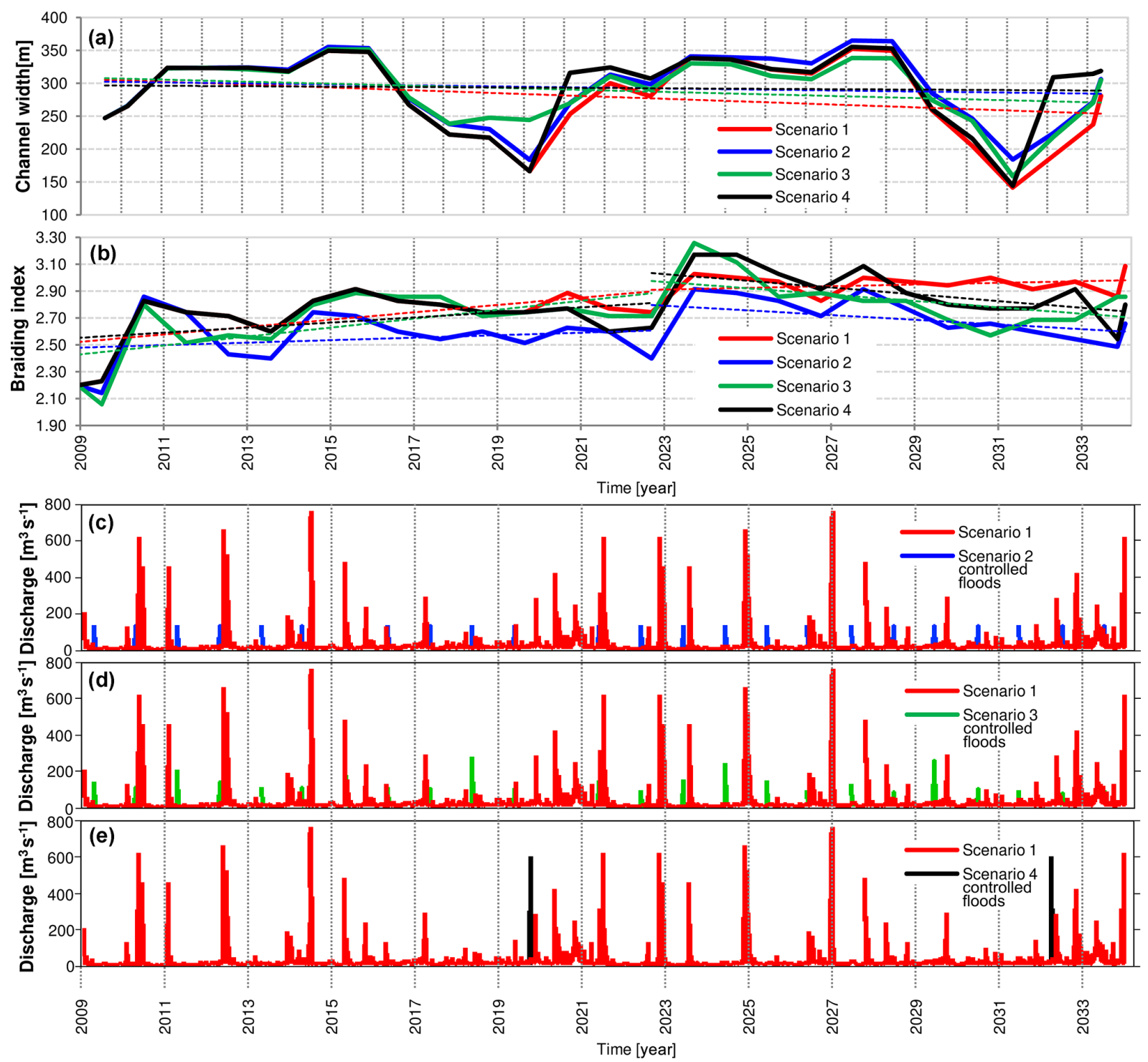

Figure 7. Scenario results expressed in terms of channel width (a) and braiding index (b) variations, coupled to the simulated upstream inflow series with controlled-flood releases: (c) scenarios 1 and 2, (d) scenario 3 and (e) scenario 4.

and the flow regime in the future scenarios, whereas this is not always the case in the past evolution. This is exemplified by the major 2002 flood event, which did not re-widen the river to the levels of 1999 (about $342 \mathrm{~m}$ ), despite being significant in terms of magnitude (13-year RI). Indeed, the width the following year (2003) was approximately $289 \mathrm{~m}$, about $15 \%$ less than in 1999 . This suggests that after a period (phases I and II in Fig. 3) of morphological instability characterized by a narrowing tendency, the studied reach had acquired a new morphological equilibrium configuration characterized by periodic oscillations in channel width. Similar new equilibrium conditions, mainly controlled by the flow regime (i.e. frequency and magnitude of formative discharges) and vegetation establishment, have been observed in the Tagliamento River (Ziliani and Surian, 2016).
The comparison of our four simulations shows that a few high-magnitude floods provide slightly better morphological recovery and conservation than small yearly floods and at a significantly lower operational cost. Therefore, $\mathrm{SC} 4$ is preferable to SC2 and SC3 from a purely morphodynamic point of view. Nevertheless, the comparison suggests that (i) none of the CF scenarios can significantly change long-term channel width and braiding intensity trends and (ii) CF releases have no significant morphological benefits and do not represent a solution for the morphological recovery of braided rivers that suffered strong and historical impacts in terms of flow and sediment supply regimes. It is worth noting that the selected $\mathrm{CFs}$ are feasible, i.e. taking into account the water infrastructure in the Piave River basin, and it is unlikely that higher-magnitude or more frequent floods could be re- 
Table 3. Description of the CAESAR-LISFLOOD model calibrated factors.

\begin{tabular}{|c|c|c|c|}
\hline \multirow[t]{2}{*}{ Factor $^{\mathrm{a}}$} & \multicolumn{2}{|c|}{ Investigated range } & \multirow{2}{*}{$\begin{array}{r}\text { Calibration } \\
\text { setting }\end{array}$} \\
\hline & Min & Max & \\
\hline Lateral erosion rate $(-)$ & 0.002 & 600 & 30 \\
\hline Maximum erosion limit (m) & 0.001 & 0.075 & 0.01 \\
\hline Active-layer thickness (m) & 0.004 & 0.28 & 0.04 \\
\hline Number of passes for edge-smoothing filter $(-)$ & 30 & 200 & 150 \\
\hline Water depth above which erosion can happen $(\mathrm{m})$ & 0.01 & 0.15 & 0.15 \\
\hline Bedload solid transport formula ${ }^{\mathrm{b}}$ & 0 & 1 & 1 \\
\hline Vegetation critic shear $\left(\mathrm{N} \mathrm{m}^{-2}\right)$ & 0.7 & 180 & 0.9 \\
\hline Vegetation maturity (year) & 0.06 & 20 & 4 \\
\hline Courant number $(-)$ & 0.1 & 0.7 & 0.2 \\
\hline Input-output difference allowed $\left(\mathrm{m}^{3} \mathrm{~s}^{-1}\right)$ & 1 & 5 & 5 \\
\hline In-channel lateral erosion rate $\left(\mathrm{N} \mathrm{m}^{-2}\right)$ & 1 & 30 & 10 \\
\hline Slope for edge cells ${ }^{c}(-)$ & - & - & 0.005 \\
\hline Sediment proportion recirculated ${ }^{\mathrm{d}}(-)$ & - & - & 1 \\
\hline
\end{tabular}

${ }^{a}$ All factors are configurable using the graphical user interface; ${ }^{b} 0$ - Einstein (1950) formula; 1 - Wilcock and Crowe (2003) formula; ${ }^{\mathrm{c}}$ factor not included in the old CAESAR model version; ${ }^{\mathrm{d}}$ factor not calibrated.

Table 4. Results of CAESAR-LISFLOOD calibration.

\begin{tabular}{lrr}
\hline & $\begin{array}{r}\text { Observed } \\
\text { active } \\
\text { channel } \\
2009\end{array}$ & $\begin{array}{r}\text { CAESAR- } \\
\text { LISFOOD } \\
\text { result }\end{array}$ \\
& $\begin{array}{l}\text { (rasterized } \\
\text { data at }\end{array}$ \\
& $10 \times 10 \mathrm{~m})$ & \\
\hline Active-channel width (m) & 241 & 247 \\
Active-channel width change in 2003-2009 period (m) & -35 & -29 \\
Wet-area width (m) & 51 & 66 \\
Braiding index (channel counted) & 1.69 & 1.71 \\
Performance of active channel (\%) & & $54.2 \%$ \\
Performance of vegetated area (\%) & & $69.7 \%$ \\
Performance of wet area (\%) & & $15.7 \%$ \\
\hline
\end{tabular}

leased. These results partially confirm the outcomes of Hicks et al. (2003) on the Waitaki River, a gravel-bed river with similar characteristics to those of the Piave River. The authors state that the frequent release of "channel maintenance floods" from dams should be pursued if wider and more active channels are desired. Hicks et al. (2003) showed that this kind of strategy has been unsuccessful and only multi-year high-magnitude CFs can produce effective channel widening.

The cost of CFs is probably less than that of alternative strategies focused on increasing sediment supply, such as sediment augmentation, because flood releases often do not require redesigning reservoir structures. Nevertheless, the reintroduction of flood flows implies a "loss" of resources stocked for other purposes (e.g. hydroelectric production and the supply of drinking or irrigation water). Another feasible way for sediment augmentation is the removal (at least in part) of non-strategic bank protections along the reach. However, as Picco et al. (2017) suggested, this kind of strategy should be a last resort, since these structures are still viewed by local populations as necessary to protect riparian woodlands that are highly appreciated for recreation and timber production.

Overall, this work gives useful insights for the management of the Piave River and, in general, for the management of braided rivers with heavily impacted flow and sediment regimes: (i) none of the tested controlled-flood strategies can significantly change ongoing morphological evolution and (ii) the baseline scenario, without controlled-flood releases (i.e. the no-action strategy), provides a similar morphological evolutionary trajectory to that induced by the controlledflood release scenarios. Therefore, a main outcome is that controlled-floods (including high-magnitude floods; e.g. 5year RI) may not have any significant effects on regulated 
rivers, specifically if formative discharges have been strongly altered.

\subsection{Assessment of CAESAR-LISFLOOD performance}

Ziliani et al. (2013) concluded that the main reasons for the poor morphological response of CAESAR are (i) DEM cell size, which has been pointed out in others works (DoeschlWilson and Ashmore, 2005; Doeschl et al., 2006; Nicholas and Quine, 2007); (ii) the quality of data (i.e. lack of wetchannel topography); and (iii) the low-flow period removal and therefore the elimination of the consequent morphological "gardening" phenomena (Ziliani et al., 2013). The combination of these factors produced a smoother and simpler braided morphology. The Piave case study represents an effort to achieve a better performance by (i) the flow routine refinement included in the LISFLOOD-FP module (one of the most recent and advanced reduced-complexity hydraulic model schemes), (ii) the adoption of higher-quality input data (higher-resolution DEM, bathymetry and hourly boundary conditions) and (iii) the code conversion in parallel programming methods. The results lead to an overall improvement of the model performance considering (i) the good channel width performance in the calibration phase; (ii) the excellent reproduction of braiding complexity, including the pioneering and complex island dynamics, both in the calibration and the long-term simulations; (iii) the reasonable estimation of bedload transport and the small changes in bed grain size in the long-term simulations (e.g. $D_{50}$ changed from $24.9 \mathrm{~mm}$ to $22.7,24.3,23.6$ and $23.1 \mathrm{~mm}$, respectively, in $\mathrm{SC} 1, \mathrm{SC} 2$, $\mathrm{SC} 3$ and SC4); and (iv) the adequate computation speed, close to what was expected (about $10 \mathrm{~d}$ of computation for 25 years of hourly series).

The suitability of RCMs for investigating river dynamics has been discussed in several studies (Doeschl-Wilson and Ashmore, 2005; Brasington and Richards, 2007; Nicholas and Quine, 2007; Murray, 2007; Nicholas, 2012, 2013b; Ziliani et al., 2013; Ziliani and Surian, 2016). A general conclusion of these works is that RCMs provide unrealistic and highly sensitive morphological responses to model grid resolution. These problems are commonly interpreted as a direct consequence of the adoption of flow routing schemes that neglect the momentum conservation and the use of local bed slopes in calculating bedload transport (e.g. through the application of the uniform-flow approximation).

The C-L model can be considered a useful tool in the search of an effective combination of simplicity and physical realism in the context of reduced-complexity modelling, overcoming problems associated with earlier simplified hydrodynamic models. The encouraging results of this case study suggest that the effort to develop this RCM is justified. While the physical realism of flow and morphodynamic rules remain unsolved at small scales (scales below the DEM cell dimension), the superiority of the C-L model over the earlier CAESAR model is evident at the reach scale. Reduced- complexity models will probably not provide answers to key reductionist questions of hydraulic engineers and fluvial geomorphologists, but the model nevertheless can provide useful insights for management, specifically about macromorphological river features (e.g. average channel width and braiding intensity) and adjustments (e.g. prediction of future evolutionary trajectory) of braided rivers.

The inherent limitations of reduced-complexity models do not preclude using RCMs to represent behaviour at the mesoscale rather than making reductionist predictions that are theoretically more accurate in quantitative terms. Reproducing morphodynamic processes at each scale requires necessarily some forms of simplification, regardless of the level of complexity of the model adopted. Nevertheless, this is not a sufficient reason to call into question the usefulness of applying this kind of model in a real-world situation. In the light of the results of this work and of the limitations of reductionist approaches (Williams et al., 2016), we believe that RCMs and specifically the C-L model are attractive options for simulating river evolution historically and into the future, i.e. at the scale of interest for river management.

This work presents another case study in which an RCM provided plausible outputs regarding a large gravel-bed river, especially in terms of evolutionary trajectories. The suitability in reproducing macromorphological features and mesoscale processes should no longer be in doubt (Nicholas, 2013b). The capability of modelling small-scale phenomena remains open for RCMs as for all CFDs that are applied to reproduce phenomena deeply influenced by initial and boundary conditions, for which a data gap persists for future scenario applications in natural contexts where the addition of modelling details does not guarantee a significant reduction of the overall uncertainty associated with modelling results.

\section{Conclusions}

Hydrological and morphodynamic models have been applied to assess the long-term geomorphic effectiveness of controlled-flood strategies. The simulated future scenarios (with a duration of 25 years) show that (i) none of the CF strategies provide significant long-term morphological benefits or reverse ongoing channel width trends (it is worth noting that the selected CFs are feasible and that it is unlikely that higher-magnitude or more frequent floods could be released) and (ii) a small number of high-magnitude floods (i.e. SC4) provide slightly better morphological recovery than do yearly low-magnitude floods (i.e. SC2 and SC3), as well as have a significantly lower operational cost (the cumulative volume released in $\mathrm{SC} 4$ is an order of magnitude lower than in SC2 and SC3). These results suggest that this kind of strategy does not represent a solution for morphological recovery in strongly and historically impacted braided rivers.

This study confirms the suitability of RCMs for modelling future long-term scenarios at spatial and temporal scales 
that are not well supported by two-dimensional to threedimensional CFD morphodynamic models. From the morphological perspective, the C-L model has proven to be capable of reproducing variations in channel width, preserving the complexity of morphological braiding, including vegetation dynamics, and reasonably estimating average bedload sediment yield. The performance assessment shows that the C-L model performs significantly better than previous CAESAR model versions (Ziliani et al. 2013). While the RCM does not provide insights into the spatial and temporal scales of interest for a traditional reductionist approach (e.g. single branch and bar dynamics or local bank erosion), it does provide useful indications for the management of braided rivers at mesoscales.

Code availability. The CAESAR-LISFLOOD model code is freely available at https://sourceforge.net/projects/caesar-lisflood/ (last access: 19 June 2020) (Sourceforge, 2020).

Data availability. Lidar data and aerial photos (2003) are available upon request to the Autorità di Bacino delle Alpi Orientali. Hydrological data are available upon request to the Environmental Regional Agency (ARPA Veneto). Aerial photos (2009) and cross sections are freely available upon request to the authors.

Supplement. The supplement related to this article is available online at: https://doi.org/10.5194/hess-24-3229-2020-supplement.

Author contributions. LZ and NS designed the research. LZ performed most of the analyses. GB aided as an expert in hydrology and hydrological modelling. LM provided guidance on sediment transport. All authors jointly contributed to the discussion and interpretation of the data. The paper was prepared by LZ, with contributions from NS, GB and LM. NS managed and coordinated research activities.

Competing interests. The authors declare that they have no conflict of interest.

Acknowledgements. This research was supported by funds from the University of Padua through the strategic project "GEO-RISKS" and DOR funds. We would like to thank the Autorità di Bacino delle Alpi Orientali for providing the lidar data. We thank the two reviewers, Tom Coulthard and an anonymous reviewer, for useful and constructive comments.

Review statement. This paper was edited by Jim Freer and reviewed by Tom Coulthard and one anonymous referee.

\section{References}

Abad, J. D., Buscaglia, G. C., and Garcia, M. H.: 2D stream hydrodynamic, sediment transport and bed morphology model for engineering applications, Hydrol. Process., 22, 1443-1459, https://doi.org/10.1002/hyp.6697, 2008.

Acreman, M. C. and Ferguson, A. J. D.: Environmental flows and the European Water Framework Directive, Freshwater Biol., 55, 32-48, https://doi.org/10.1111/j.1365-2427.2009.02181.x, 2010.

Allen, J. I., Holt, J. T., Blackford, J., and Proctor, R.: Error quantification of a high-resolution coupled hydrodynamicecosystem coastal-ocean model: Part 2. Chlorophyll$a$, nutrients and SPM, J. Mar. Syst., 68, 381-404, https://doi.org/10.1016/j.jmarsys.2007.01.005, 2007.

Aronica, G., Bates, P. D., and Horritt, M. S.: Assessing the uncertainty in distributed model predictions using observed binary pattern information within GLUE, Hydrol. Process., 16, 2001-2016, https://doi.org/10.1002/hyp.398, 2002.

Ashmore, P. E.: Channel morphology and bed load pulses in braided gravel-bed streams, Geograf. Ann. A, 73, 37-52, 1991.

ASME: Statement upon the Control of Numerical Accuracy, J. Fluids Eng., 115, 339-340, 1993.

Basso, S., Schirmer, M., and Botter, G.: On the emergence of heavytailed streamflow distributions, Adv. Water Resour., 82, 98-105, https://doi.org/10.1016/j.advwatres.2015.04.013, 2015.

Bates, P. D. and De Roo, A. P. J.: A simple raster-based model for flood inundation simulation, J. Hydrol., 236, 54-77, https://doi.org/10.1016/S0022-1694(00)00278-X, 2000.

Bates, P. D., Horritt, M. S., and Fewtrell, T. J.: A simple inertial formulation of the shallow water equations for efficient twodimensional flood inundation modelling, J. Hydrol., 387, 33-45, https://doi.org/10.1016/j.jhydrol.2010.03.027, 2010.

Bertoldi, W., Gurnell, A., and Drake, N. A.: The topographic signature of vegetation development along a braided river: Results of a combined analysis of airborne LiDAR, color air photographs, and ground measurements, Water Resour. Res., 47, W06525, https://doi.org/10.1029/2010WR010319, 2011.

Bilotta, G. S. and Brazier, R. E.: Understanding the influence of suspended solids on water quality and aquatic biota, Water Res., 42, 2849-2861, https://doi.org/10.1016/j.watres.2008.03.018, 2008.

Bliesner, R., De La Hoz, E., Holden, P., and Lamara, V.: San Juan River Basin Recovery Implementation Program, in: Hydrology geomorphology and habitat studies, 2008 Annual Report, available at: https://www.fws.gov/southwest/sjrip/pdf/SJW2/ Bliesner_et_al._(2008)_Hydrology,_Geomorphology_and_ Habitat_Studies.pdf (last access: 18 June 2020), 2009.

Bocchiola, D. and Rosso, R.: Safety of Italian dams in the face of flood hazard, Adv. Water Resour., 71, 23-31, https://doi.org/10.1016/j.advwatres.2014.05.006, 2014.

Botter, G., Porporato, A., Rodriguez-Iturbe, I., and Rinaldo, A.: Basin-scale soil moisture dynamics and the probabilistic characterization of carrier hydrologic flows: Slow, leaching-prone components of the hydrologic response, Water Resour. Res., 43, W02417, https://doi.org/10.1029/2006WR005043, 2007.

Botter, G., Basso, S., Porporato, A., Rodriguez-Iturbe, I., and Rinaldo, A.: Natural streamflow regime alterations: Damming of the Piave River basin (Italy), Water Resour. Res., 46, W06522, https://doi.org/10.1029/2009WR008523, 2010.

Braidot, A.: Relazione sulle piene del novembre 2002, Cinque Fiumi, Autorità di Bacino dell'Alto Adriatico, Venice, 2-3, 2003. 
Brasington, J. and Richards, K.: Reduced-complexity, physically-based geomorphological modelling for catchment and river management, Geomorphology, 90, 171-177, https://doi.org/10.1016/j.geomorph.2006.10.028, 2007.

Céréghino, R., Legalle, M., and Lavandier, P.: Drift and benthic population structure of the mayfly Rhithrogena semicolorata (Heptageniidae) under natural and hydropeaking conditions, Hydrobiologia, 519, 127-133, https://doi.org/10.1023/B:HYDR.0000026499.53979.69, 2004.

Chen, D. and Duan, J.: Case Study: Two-Dimensional Model Simulation of Channel Migration Processes in West Jordan River, Utah, J. Hydraul. Eng., 134, 315-327, https://doi.org/10.1061/(ASCE)0733-9429(2008)134:3(315), 2008.

Collier, K. J.: Effects of flow regulation and sediment flushing on instream habitat and benthic invertebrates in a New Zealand river influenced by a volcanic eruption, River Res. Appl., 18, 213-226, https://doi.org/10.1002/rra.666, 2002.

Comiti, F.: How natural are Alpine mountain rivers? Evidence from the Italian Alps, Earth Surf. Proc. Land., 37, 693-707, https://doi.org/10.1002/esp.2267, 2012.

Comiti, F., Da Canal, M., Surian, N., Mao, L., Picco, L., and Lenzi, M. A.: Channel adjustments and vegetation cover dynamics in a large gravel bed river over the last 200 years, Geomorphology, 125, 147-159, https://doi.org/10.1016/j.geomorph.2010.09.011, 2011.

Coulthard, T. J. and Van De Wiel, M. J.: Numerical Modeling in Fluvial Geomorphology, in: Treatise on Geomorphology, edited by: Shroder, J. F., Academic Press, San Diego, 694-710, 2013.

Coulthard, T. J. and Van De Wiel, M. J.: Modelling long term basin scale sediment connectivity, driven by spatial land use changes, Geomorphology, 277, 265-281, https://doi.org/10.1016/j.geomorph.2016.05.027, 2017.

Coulthard, T. J., Macklin, M. G., and Kirkby, M. J.: A cellular model of Holocene upland river basin and alluvial fan evolution, Earth Surf. Proc. Land., 2, 269-288, https://doi.org/10.1002/esp.318, 2002.

Coulthard, T. J., Kirkby, M. J., and Macklin, M. G.: Modelling differential catchment response to environmental change, Geomorphology, 69, 222-241, 2005.

Coulthard, T. J., Hicks, D. M., and Van De Wiel, M. J.: Cellular modelling of river catchments and reaches: Advantages, limitations and prospects, Geomorphology, 90, 192-207, https://doi.org/10.1016/j.geomorph.2006.10.030, 2007.

Coulthard, T. J., Neal, J. C., Bates, P. D., Ramirez, J., de Almeida, G. A. M., and Hancock, G. R.: Integrating the LISFLOOD-FP 2D hydrodynamic model with the CAESAR model: Implications for modelling landscape evolution, Earth Surf. Proc. Land., 38, 1897-1906, 2013.

Da Canal, M., Comiti, F., Surian, N., Mao, L., and Lenzi, M. A.: Studio delle variazioni morfologiche del F. Piave nel Vallone Bellunese durante gli ultimi 200 anni, Quaderni di Idronomia Montana, 27, 259-271, 2007

Darby, S. E. and Van De Wiel, M. J.: Models in Fluvial Geomorphology, in: Tools in Fluvial Geomorphology, edited by: Kondolf, M. G. and Piegay, H., John Wiley \& Sons Ltd, Chichester, 503-537, 2003.

Darby, S. E., Alabyan, A. M., and Van de Wiel, M. J.: Numerical simulation of bank erosion and channel migra- tion in meandering rivers, Water Resour. Res., 38, 2-1-2-21, https://doi.org/10.1029/2001WR000602, 2002.

Defina, A.: Numerical experiments on bar growth, Water Resour. Res., 39, ESG21-ESG212, https://doi.org/10.1029/2002WR001455, 2003.

Del Favero, R. and Lasen, C.: La vegetazione forestale del Veneto, Libreria Progetto, Padova, 1993.

Doeschl, A. B., Ashmore, P. E., and Davison, M.: Methods for assessing exploratory computational models of braided rivers, in: Braided Rivers, edited by: Sambrook Smith, G. H., Best, J. L., Bristow, C., and Petts, G. E., IAS Special Publ., 36, 177-197, 2006.

Doeschl-Wilson, A. B. and Ashmore, P. E.: Assessing a numerical cellular braided-stream model with a physical model, Earth Surf. Proc. Land., 30, 519-540, https://doi.org/10.1002/esp.1146, 2005.

Dyer, F. J. and Thoms, M. C.: Managing river flows for hydraulic diversity: An example of an upland regulated gravel-bed river, River Res. Appl., 22, 257-267, https://doi.org/10.1002/rra.909, 2006.

Egozi, R. and Ashmore, P. E.: Defining and measuring braiding intensity, Earth Surf. Proc. Land., 33, 2121-2138, https://doi.org/10.1002/esp.1658, 2008.

Einstein, H. A.: The bed-load function for sediment transport on open channel flows, in: Tech. Bull. 1026, USDA, Soil Conservation Service, Washington, D.C., 1950.

Environment Canterbury Regional Council: Lower Waitaki River Control Scheme Review, Options Report, in: Report No. R15/44, Christchurch, 2015.

Escauriaza, C., Paola, C., and Voller, V. R.: Computational models of flow, sediment transport and morphodynamics in rivers, in: Gravel-Bed Rivers: Process and Disasters, edited by: Tsutsumi, D. and Laronne, J. B., Wiley-Blackwell, Chichester, 1-29, 2017.

Espa, P., Crosa, G., Gentili, G., Quadroni, S., and Petts, G.: Downstream Ecological Impacts of Controlled Sediment Flushing in an Alpine Valley River: A Case Study, River Res. Appl., 31, 931942, https://doi.org/10.1002/rra.2788, 2015.

Feeney, C. J., Chiverrell, R. C., Smith, H. G., Hooke, J. M., and Cooper, J. R., Modelling the decadal dynamics of reach-scale river channel evolution and floodplain turnover in CAESAR-Lisflood, Earth Surf. Proc. Land., 45, 1273-1291, https://doi.org/10.1002/esp.4804, 2020.

Ferrazzi, M. and Botter, G.: Contrasting signatures of distinct human water uses in regulated flow regimes, Environ. Res. Commun., 1, 071003, https://doi.org/10.1088/2515-7620/ab3324, 2019.

Formann, E., Habersack, H. M., and Schober, S.: Morphodynamic river processes and techniques for assessment of channel evolution in Alpine gravel bed rivers, Geomorphology, 90, 340-355, https://doi.org/10.1016/j.geomorph.2006.10.029, 2007.

Frutiger, A.: Ecological impacts of hydroelectric power production on the River Ticino. Part 1: Thermal effects, Arch. Hydrobiol., 159, 43-56, https://doi.org/10.1127/00039136/2004/0159-0043, 2004.

Gaeuman, D.: Analyses to support gravel augmentation recommendations for the Trinity River, California, Trinity River Restoration Program, in: Technical Report TR-TRRP-2014-1, Weaverville, CA, 2014. 
Gaeuman, D., Schmidt, J. C., and Wilcock, P. R.: Complex channel responses to changes in stream flow and sediment supply on the lower Duchesne River, Utah, Geomorphology, 64, 185-206, https://doi.org/10.1016/j.geomorph.2004.06.007, 2005.

Gore, J. and Petts, G. E.: Alternatives in regulated river management, CRC Press, Boca Raton, Florida, 1989.

Graf, W. L.: The effect of dam closure on downstream rapids, Water Resour. Res., 16, 129-136, https://doi.org/10.1029/WR016i001p00129, 1980.

Grant, G. E.: The geomorphic response of gravel-bed rivers to dams: perspectives and prospects, in: Gravel-Bed Rivers, edited by: Church, M., Biron, P. M., and Roy, A. G., John Wiley \& Sons Ltd, Chichester, 165-181, 2012.

Haff, P. K.: Limitations on Predictive Modeling in Geomorphology, in: The Scientific Nature of Geomorphology, edited by: Rhoads, B. L. and and Thorn, C. E., Proceedings of the 27th Binghamton Symposium in Geomorphology, 27-29 September 1996, 337358, 1996.

Hall, J. W., Tarantola, S., Bates, P. D., and Horritt, M. S.: Distributed sensitivity analysis of flood inundation model calibration, J. Hydraul. Eng., 131, 117-126, https://doi.org/10.1061/(ASCE)07339429(2005)131:2(117), 2005.

Ham, D. G. and Church, M.: Bed-material transport estimated from channel morphodynamics: Chilliwack River, British Columbia, Earth Surf. Proc. Land., 25, 1123-1142, 2000.

Henriksen, H. J., Troldborg, L., Nyegaard, P., Sonnenborg, T. O., Refsgaard, J. C., and Madsen, B.: Methodology for construction, calibration and validation of a national hydrological model for Denmark, J. Hydrol., 280, 52-71, https://doi.org/10.1016/S00221694(03)00186-0, 2003.

Hicks, D. M., Duncan, M. J., Shankar, U., Wild, M., and Walsh, J. R.: Project Aqua: Lower Waitaki River geomorphology and sediment transport, National Institute of Water \& Atmospheric Research, Christchurch, 195 pp., 2003.

Hicks, D. M., Single, M., and Hall, R. J.: Geomorphic character, controls, processes and history of the Waitaki Coast - a primer, Prepared for Meridian Energy, Christchurch, 103 pp., 2006.

Hoey, T., Bishop, P., and Ferguson, R. I.: Testing Numerical Models in Geomorphology: How can we Ensure Critical use of Model Prediction? in: Prediction in geomorphology, edited by: Wilcock, P. R. and Iverson, R. M., American Geophysical Union, Washington, D.C., 241-256, 2003.

Horritt, M. S. and Bates, P. D.: Predicting floodplain inundation: Raster-based modelling versus the finite-element approach, Hydrol. Process., 15, 825-842, https://doi.org/10.1002/hyp.188, 2001.

Kondolf, G. M., Gao, Y., Annandale, G. W., Morris, G. L., Jiang, E., Zhang, J., Cao, Y., Carling, P., Fu, K., Guo, Q., Hotchkiss, R., Peteuil, C., Sumi, T., Wang, H., Wang, Z., Wei, Z., Wu, B., Wu, C., and Yang, C. T.: Sustainable sediment management in reservoirs and regulated rivers: Experiences from five continents, Earth's Future, 2, 256-280, https://doi.org/10.1002/2013EF000184, 2014.

Konrad, C. P., Olden, J. D., Lytle, D. A., Melis, T. S., Schmidt, J. C., Bray, E. N., Freeman, M. C., Gido, K. B., Hemphill, N. P., Kennard, M. J., McMullen, L. E., Mims, M. C., Pyron, M., Robinson, C. T., and Williams, J. G.: Large-scale flow experiments for managing river systems, Bioscience, 61, 948-959, https://doi.org/10.1525/bio.2011.61.12.5, 2011.
Konrad, C. P., Warner, A., and Higgins, J. V.: Evaluating dam re-operation for freshwater conservation in the sustainable rivers project, River Res. Appl., 28, 777-792, https://doi.org/10.1002/rra.1524, 2012.

Lane, E. W.: Design of stable channels, T. Am. Soc. Civ. Eng., 120, 1234-1260, 1955.

Lane, S. N.: Approaching the system-scale understanding of braided river behaviour, in: Braided Rivers, edited by: Sambrook Smith, G. H., Best, J. L., Bristow, C., and Petts, G. E., IAS Special Publ., 36, 107-135, 2006.

Lane, S. N., Hardy, R. J., Ferguson, R. I., and Parsons, D. R.: A Framework for Model Verification and Validation of CFD Schemes in Natural Open Channel Flows, in: Computational Fluid Dynamics, edited by: Bates, P. D., Lane, S. N., and Ferguson, R. I., John Wiley \& Sons Ltd, Chichester, 169-192, 2005.

Larsen, L., Thomas, C., Eppinga, M., and Coulthard, T., Exploratory modeling: extracting causality from complexity, Eos Trans. Am. Geophys. Union, 95, 285-287, 2014.

Legleiter, C. J., Roberts, D. A., and Lawrence, R. L.: Spectrally based remote sensing of river bathymetry, Earth Surf. Proc. Land., 34, 1039-1059, https://doi.org/10.1002/esp.1787, 2009.

Lehner, B., Liermann, C. R., Revenga, C., Vörösmarty, C., Fekete, B., Crouzet, P., Döll, P., Endejan, M., Frenken, K., Magome, J., Nilsson, C., Robertson, J. C., Rödel, R., Sindorf, N., and Wisser, D.: High-resolution mapping of the world's reservoirs and dams for sustainable river-flow management, Front. Ecol. Environ., 9, 494-502, https://doi.org/10.1890/100125, 2011.

Leopold, L. B.: A View of the River, Harvard University Press, Cambridge, MA, 1994.

Lewis, M., Bates, P., Horsburgh, K., Neal, J. C., and Schumann, G.: A storm surge inundation model of the northern Bay of Bengal using publicly available data, Q. J. Rpy. Meteorol. Soc., 139, 358-369, https://doi.org/10.1002/qj.2040, 2013.

Li, S. S., Millar, R. G., and Islam, S.: Modelling gravel transport and morphology for the Fraser River Gravel Reach, British Columbia, Geomorphology, 95, 206-222, https://doi.org/10.1016/j.geomorph.2007.06.010, 2008.

Liebault, F., Piegay, H., Frey, P., and Landon, N.: Tributaries and the management of main-stem geomorphology, in: River Confluences, Tributaries and the Fluvial Network, edited by: Rice, S. P., Roy, A., and Rhoads, B. L., Wiley, Chichester, 2008.

Lobera, G., Batalla, R.J., Vericat, D., Lopez-Tarazon, J. A., and Tena, A.: Sediment transport in two mediterranean regulated rivers, Sci. Total Environ., 540, 101-113, https://doi.org/10.1016/j.scitotenv.2015.08.018, 2016.

Magilligan, F. J. and Nislow, K. H.: Changes in hydrologic regime by dams, Geomorphology, 71, 61-78, https://doi.org/10.1016/j.geomorph.2004.08.017, 2005.

Magilligan, F. J., Nislow, K. H., and Renshaw, C. E.: Flow Regulation by Dams, in: Treatise on Geomorphology, edited by: Shroder, J. F., Academic Press, San Diego, 794-808, 2013.

Mao, L. and Surian, N.: Observations on sediment mobility in a large gravel-bed river, Geomorphology, 114, 326-337, https://doi.org/10.1016/j.geomorph.2009.07.015, 2010.

Mao, L., Picco, L., Lenzi, M. A., and Surian, N.: Bed material transport estimate in large gravel-bed rivers using the virtual velocity approach, Earth Surf. Proc. Land., 42, 595-611, https://doi.org/10.1002/esp.4000, 2017. 
Marcus, W. A.: Remote Sensing of the Hydraulic Environment in Gravel-Bed Rivers, in: Gravel-Bed Rivers, edited by: Church, M., Biron, P. M.. and Roy, A. G., John Wiley \& Sons Ltd, Chichester, 259-285, 2012.

Martin, Y. and Church, M.: Bed-material transport estimated from channel surveys: Vedder River, British Columbia, Earth Surf. Proc. Land., 20, 347-361, 1995.

Martínez Santa-María, C. and Fernández Yuste, J. A.: IAHRIS Índices de Alteración Hidrológica en Ríos, Manual de Referencia Metodológica, Versión 1, available at: https://www.chduero.es/ documents/20126/734183/iharis.pdf (last access: 19 June 2020), 2008.

McDonald, R., Nelson, J., Paragamian, V., and Barton, G.: Modeling the effect of flow and sediment transport on white sturgeon spawning habitat in the Kootenai River, Idaho, J. Hydraul. Eng., 136, 1077-1092, https://doi.org/10.1061/(ASCE)HY.19437900.0000283, 2010.

McKinney, T., Speas, D. W., Rogers, R. S., and Persons, W. R.: Rainbow trout in a regulated river below Glen Canyon Dam, Arizona, following increased minimum flows and reduced discharge variability, N. Am. J. Fish. Manage., 21, 216-222, 2001.

McManamay, R. A., Orth, D. J., and Dolloff, C. A.: Macroinvertebrate Community Responses to Gravel Addition in a Southeastern Regulated River, Southeast. Nat., 12, 599-618, 2013.

Melis, T. S.: Effects of three high-flow experiments on the Colorado River ecosystem downstream from Glen Canyon Dam, Arizona, in: US Geological Survey Circular 1366, US Geological Survey, Reston, VA, 147 pp, 2011.

Mosselman, E.: Modelling Sediment Transport and Morphodynamics of Gravel-Bed Rivers, in: Gravel-Bed Rivers, edited by: Church, M., Biron, P. M., and Roy, A. G., John Wiley \& Sons Ltd, Chichester, 101-115, 2012.

Mueller, E. R., Grams, P. E., Schmidt, J. C., Hazel, J. E., Alexander, J. S., and Kaplinski, M.: The influence of controlled floods on fine sediment storage in debris fan-affected canyons of the Colorado River basin, Geomorphology, 226, 65-75, https://doi.org/10.1016/j.geomorph.2014.07.029, 2014.

Murray, A. B.: Reducing model complexity for explanation and prediction, Geomorphology, 90, 178-191, https://doi.org/10.1016/j.geomorph.2006.10.020, 2007.

Murray, A. B. and Paola, C.: A cellular model of braided rivers, Nature, 371, 54-57, https://doi.org/10.1038/371054a0, 1994.

Neal, J. C., Villanueva, I., Wright, N., Willis, T., Fewtrell, T., and Bates, P. D.: How much physical complexity is needed to model flood inundation?, Hydrol. Process., 26, 2264-2282, https://doi.org/10.1002/hyp.8339, 2012.

Nicholas, A. P.: Modelling bedload yield braided gravel bed rivers, Geomorphology, 36, 89-106, https://doi.org/10.1016/S0169555X(00)00050-7, 2000.

Nicholas, A. P.: Reduced-complexity flow routing models for sinuous single-thread channels: Intercomparison with a physicallybased shallow-water equation model, Earth Surf. Proc. Land., 34, 641-653, https://doi.org/10.1002/esp.1761, 2009.

Nicholas, A. P.: Reduced-complexity modeling of free bar morphodynamics in alluvial channels, J. Geophys. Res.-Earth, 115, F04021, https://doi.org/10.1029/2010JF001774, 2010.

Nicholas, A. P.: Morphodynamic diversity of the world's largest rivers, Geology, 41, 475-478, https://doi.org/10.1130/G34016.1, 2013a.
Nicholas, A. P.: Morphodynamic Modeling of Rivers and Floodplains, in: Treatise on Geomorphology, edited by: Shroder, J. F., Academic Press, San Diego, 2013b.

Nicholas, A. P. and Quine, T. A.: Crossing the divide: Representation of channels and processes in reduced-complexity river models at reach and landscape scales, Geomorphology, 90, 318-339, https://doi.org/10.1016/j.geomorph.2006.10.026, 2007.

Nicholas, A. P., Thomas, R., and Quine, T. A.: Cellular modelling of braided river form and process, in: Braided Rivers, edited by: Sambrook Smith, G. H., Best, J. L., Bristow, C., and Petts, G. E., IAS Special Publ., 36, 137-151, 2006.

Nicholas, A. P., Sandbach, S. D., Ashworth, P. J., Amsler, M. L., Best, J. L., Hardy, R. J., Lane, S. N., Orfeo, O., Parsons, D. R., Reesink, A. J. H., Sambrook Smith, G. H., and Szupiany, R. N.: Modelling hydrodynamics in the Rio Paraná, Argentina: An evaluation and inter-comparison of reduced-complexity and physics based models applied to a large sand-bed river, Geomorphology, 169-170, 192-211, https://doi.org/10.1016/j.geomorph.2012.05.014, 2012.

O'Connor, J. E., Duda, J. J., and Grant, G. E.: 1000 dams down and counting: Dam removals are reconnecting rivers in the United States, Science, 348, 496-497, https://doi.org/10.1126/science.aaa9204, 2015.

Olden, J. D. and Naiman, R. J.: Incorporating thermal regimes into environmental flows assessments: Modifying dam operations to restore freshwater ecosystem integrity, Freshwater Biol., 55, 86107, https://doi.org/10.1111/j.1365-2427.2009.02179.x, 2010.

Olden, J. D., Konrad, C. P., Melis, T. S., Kennard, M. J., Freeman, M. C., Mims, M. C., Bray, E. N., Gido, K. B., Hemphill, N. P., Lytle, D. A., McMullen, L. E., Pyron, M., Robinson, C. T., Schmidt, J. C., and Williams, J. G.: Are large-scale flow experiments informing the science and management of freshwater ecosystems?, Front. Ecol. Environ., 12, 176-185, https://doi.org/10.1890/130076, 2014.

Oreskes, N., Shrader-Frechette, K., and Belitz, K.: Verification, validation, and confirmation of numerical models in the earth sciences, Science, 263, 641-646, 1994.

Overeem, I., Kettner, A. J., and Syvitski, J. P. M.: Impacts of Humans on River Fluxes and Morphology, in: Treatise on Geomorphology, edited by: Shroder, J. F., Academic Press, San Diego, 828-842, 2013.

Paetzold, A., Yoshimura, C., and Tockner, K.: Riparian arthropod responses to flow regulation and river channelization, J. Appl. Ecol., 45, 894-903, 2008.

Papanicolaou, A. N., Elhakeem, M., Krallis, G., Prakash, S., and Edinger, J.: Sediment transport modeling review - Current and future developments, J. Hydraul. Eng., 134, 1-14, https://doi.org/10.1061/(ASCE)0733-9429(2008)134:1(1), 2008.

Parsons, J. A. and Fonstad, M. A.: A cellular automata model of surface water flow, Hydrol. Process., 21, 2189-2195, https://doi.org/10.1002/hyp.6587, 2007.

Petts, G. E. and Gurnell, A. M.: Dams and geomorphology: Research progress and future directions, Geomorphology, 71, 2747, https://doi.org/10.1016/j.geomorph.2004.02.015, 2005.

Picco, L., Comiti, F., Mao, L., Tonon, A., and Lenzi, M. A.: Medium and short term riparian vegetation, island and channel evolution in response to human pressure in a regulated 
gravel bed river (Piave River, Italy), Catena, 149, 760-769, https://doi.org/10.1016/j.catena.2016.04.005, 2017.

Pickup, G. and Rieger, W. A.: A conceptual model of the relationship between channel characteristics and discharge, Earth Surf. Process., 4, 37-42, https://doi.org/10.1002/esp.3290040104, 1979.

Poff, N. L., Allan, J. D., Bain, M. B., Karr, J. R., Prestegaard, K. L., Richter, B. D., Sparks, R. E., and Stromberg, J. C.: The natural flow regime: A paradigm for river conservation and restoration, Bioscience, 47, 769-784, 1997.

Poff, N. L., Olden, J. D., Merritt, D. M., and Pepin, D. M.: Homogenization of regional river dynamics by dams and global biodiversity implications, P. Natl. Acad. Sci. USA, 104, 5732-5737, 2007.

Poulos, H. M., Miller, K. E., Kraczkowski, M. L., Welchel, A. W., Heineman, R., and Chernoff, B.: Fish Assemblage Response to a Small Dam Removal in the Eightmile River System, Connecticut, USA, Environ. Manage., 54, 1090-1101, https://doi.org/10.1007/s00267-014-0314-y, 2014.

Rathburn, S. L., Merritt, D. M., Wohl, E. E., Sanderson, J. S., and Knight, H. A. L.: Characterizing environmental flows for maintenance of river ecosystems: North Fork Cache la Poudre River, Colorado, in: Management and Restoration of Fluvial Systems with Broad Historical Changes and Human Impacts, Geological Society of America Special Paper 451, edited by: James, L. A., Rathburn, S. L., and Whittecar, G. R., Geological Society of America, 143-157, 2009.

Rhoads, B. L.: Statistical models of fluvial systems, Geomorphology, 5, 433-455, 1992.

Richter, B. D., Baumgartner, J. V., Powell, J., and Braun, D. P.: A method for assessing hydrologic alteration within ecosystems, Conserv. Biol., 10, 1163-1174, 1996.

Richter, B. D., Baumgartner, J. V., Wigington, R., and Braun, D. P.: How much water does a river need?, Freshwater Biol., 37, 231249, 1997.

Rinaldi, M. and Simon, A.: Bed-level adjustments in the Arno River, central Italy, Geomorphology, 22, 57-71, 1998.

Rivaes, R., Boavida, I., Santos, J. M., Pinheiro, A. N., and Ferreira, T.: Importance of considering riparian vegetation requirements for the long-term efficiency of environmental flows in aquatic microhabitats, Hydrol. Earth Syst. Sci., 21, 5763-5780, https://doi.org/10.5194/hess-21-5763-2017, 2017.

Rood, S. B., Gourley, C. R., Ammon, E. M., Heki, L. G., Klotz, J. R., Morrison, M. L., Mosley, D., Scoppettone, G. G., Swanson, S., and Wagner, P. L.: Flows for floodplain forests: A successful riparian restoration, Bioscience, 53, 647-656, 2003.

Rüther, N. and Olsen, N.: Three-Dimensional Modeling of Sediment Transport in a Narrow $90^{\circ}$ Channel Bend, J. Hydraul. Eng., 131, 917-920, https://doi.org/10.1061/(ASCE)07339429(2005)131:10(917), 2005.

Sabaton, C., Souchon, Y., Capra, H., Gouraud, V., Lascaux, J., and Tissot, L.: Long-term brown trout populations responses to flow manipulation, River Res. Appl., 24, 476-505, https://doi.org/10.1002/rra.1130, 2008.

Schaefli, B., Rinaldo, A., and Botter, G.: Analytic probability distributions for snow-dominated streamflow, Water Resour. Res., 49, 2701-2713, https://doi.org/10.1002/wrcr.20234, 2013.
Schmidt, J. C. and Wilcock, P. R.: Metrics for assessing the downstream effects of dams, Water Resour. Res., 44, W04404, https://doi.org/10.1029/2006WR005092, 2008.

Schumm, S. A.: The Fluvial System, Wiley, New York, 1977.

Schumm, S. A., Harvey, M. D., and Watson, C. C.: Incised channels: morphology, dynamics and control, Water Resources Pubns, Littleton, CO, 208 pp., 1984.

Scorpio, V., Aucelli, P. P. C., Giano, S. I., Pisano, L., Robustelli, G., Rosskopf, C. M., and Schiattarella, M.: River channel adjustments in Southern Italy over the past 150 years and implications for channel recovery, Geomorphology, 251, 77-90, https://doi.org/10.1016/j.geomorph.2015.07.008, 2015.

Shafroth, P. B., Wilcox, A. C., Lytle, D. A., Hickey, J. T., Andersen, D. C., Beauchamp, V. B., Hautzinger, A., McMullen, L. E., and Warner, A.: Ecosystem effects of environmental flows: modelling and experimental floods in a dry land river, Freshwater Biol., 55, 68-85, https://doi.org/10.1111/j.1365-2427.2009.02271.x, 2010.

Simon, A.: A model of channel response in disturbed alluvial channels, Earth Surf. Proc. Land., 14, 11-26, 1989.

Simon, A. and Hupp, C. R.: Channel widening characteristics and bank slope development along a reach of Cane Creek, West Tennessee, in: Selected Papers in Hydrologic Sciences, US Geological Survey Water-Supply Paper 2290, US Geological Survey, Reston, Virginia, 113-126, 1986.

Skinner, C. J., Coulthard, T. J., Parsons, D. R., Ramirez, J. A., Mullen, L., and Manson, S.: Simulating tidal and storm surge hydraulics with a simple 2D inertia based model, in the Humber Estuary, U.K., Estuar. Coast. Shelf Sci., 155, 126-136, 2015.

Skinner, C. J., Coulthard, T. J., Schwanghart, W., Van De Wiel, M. J., and Hancock, G., Global sensitivity analysis of parameter uncertainty in landscape evolution models, Geosci. Model Dev., 11, 4873-4888, https://doi.org/10.5194/gmd-11-4873-2018, 2018.

Souchon, Y., Sabaton, C., Deibel, R., Reiser, D., Kershner, J., Gard, M., Katopodis, C., Leonard, P., Poff, N. L., Miller, W. J., and Lamb, B. L.: Detecting biological responses to flow management: missed opportunities; future directions, River Res. Appl., 24, 506-518, https://doi.org/10.1002/rra.1134, 2008.

Sourceforge: caesar-lisflood, CAESAR-Lisflood landscape evolution model, available at: https://sourceforge.net/projects/ caesar-lisflood/, last access: 19 June 2020.

Surian, N.: The terraces of the Piave River in the Vallone Bellunese, eastern Alps, Italy, Geografica Fisica e Dinamica Quaternaria, 19, 119-127, 1996.

Surian, N.: Channel changes due to river regulation: the case of the Piave River, Italy, Earth Surf. Proc. Land., 24, 1135-1151, 1999.

Surian, N. and Cisotto, A.: Channel adjustments, bedload transport and sediment sources in a gravel-bed river, Brenta River, Italy, Earth Surf. Proc. Land., 32, 1641-1656, https://doi.org/10.1002/esp.1591, 2007.

Surian, N. and Rinaldi, M.: Morphological response to river engineering and management in alluvial channels in Italy, Geomorphology, 50, 307-326, https://doi.org/10.1016/S0169555X(02)00219-2, 2003.

Surian, N., Mao L., Giacomin, M., and Ziliani, L.: Morphological effects of different channel-forming discharges in a gravel-bed river, Earth Surf. Proc. Land., 34, 1093-1107, https://doi.org/10.1002/esp.1798, 2009a.

Surian, N., Rinaldi, M., Pellegrini, L., Audisio, C., Maraga, F., Teruggi, L., Turitto, O., and Ziliani, L.: Channel adjustments in 
northern and central Italy over the last 200 years, in: Management and Restoration of Fluvial Systems with Broad Historical Changes and Human Impacts, Geological Society of America Special Paper 451, edited by: James, L. A., Rathburn, S. L., and Whittecar, G. R., Geological Society of America, 83-95, $2009 \mathrm{~b}$.

Surian, N., Ziliani, L., Comiti, F., Lenzi, M. A., and Mao, L.: Channel adjustments and alteration of sediment fluxes in gravel-bed rivers of north-eastern Italy: Potentials and limitations for channel recovery, River Res. Appl., 25, 551-567, https://doi.org/10.1002/rra.1231, 2009c.

Thomas, R. and Nicholas, A. P.: Simulation of braided river flow using a new cellular routing scheme, Geomorphology, 43, 179195, https://doi.org/10.1016/S0169-555X(01)00128-3, 2002.

Thomas, R., Nicholas, A. P., and Quine, T. A.: Cellular modelling as a tool for interpreting historic braided river evolution, Geomorphology, 90, 302-317, 2007.

Tomasi, A.: Analisi granulometriche e caratterizzazione tessiturale di un tratto del fiume Piave compreso tra Levego e l'abitato di Nogarè, MS Thesis, Università di Trieste, Trieste, 2009.

Trinity Management Council: Trinity River Restoration Program 2013 Annual Report, Weaverville, California, 2014.

Turner, D. I.: Dams and ecology, Civ. Eng.-ASCE, 41, 76-80, 1971.

Van De Wiel, M. J., Coulthard, T. J., Macklin, M. G., and Lewin, J.: Embedding reach-scale fluvial dynamics within the CAESAR cellular automaton landscape evolution model, Geomorphology, 90, 283-301, https://doi.org/10.1016/j.geomorph.2006.10.024, 2007.

Van Fraassen, B. C.: The Scientific Image, Oxford University Press, Oxford, 1980.

Villi, V. and Bacchi B.: Valutazione delle piene nel Triveneto, CNRGNDCI Consiglio nazionale delle ricerche, Gruppo nazionale per la difesa dalle catastrofi idrogeologiche, Padova, Brescia, 2001.

Vörösmarty, C. J., Meybeck, M., Fekete, B., Sharma, K., Green, P., and Syvitski, J. P. M.: Anthropogenic sediment retention: Major global impact from registered river impoundments, Global Planet. Change, 39, 169-190, https://doi.org/10.1016/S09218181(03)00023-7, 2003.

Wang, G., Xia, J., and Wu, B.: Numerical Simulation of Longitudinal and Lateral Channel Deformations in the Braided Reach of the Lower Yellow River, J. Hydraul. Eng., 134, 1064-1078, https://doi.org/10.1061/(ASCE)0733-9429(2008)134:8(1064), 2008.

Watts, R. J., Richter, B. D., Opperman, J. J., and Bowmer, K. H.: Dam reoperation in an era of climate change, Mar. Freshwater Res., 62, 321-327, https://doi.org/10.1071/MF10047, 2011.

Wilcock, P. R. and Crowe, J. C.: Surface-based transport model for mixed-size sediment, J. Hydraul. Eng., 129, 120-128, 2003.

Wilcock, P. R. and Iverson, R. M.: Prediction in geomorphology, in: Prediction in geomorphology, edited by: Wilcock, P. R. and Iverson, R. M., American Geophysical Union, Washington, D.C., 3-14, 2003.

Williams, G. P.: Bank-full discharge of rivers, Water Resour. Res., 14, 1141-1154, https://doi.org/10.1029/WR014i006p01141, 1978.

Williams, G. P. and Wolman, M. G.: Downstream effects of dams on alluvial rivers, US Geological Survey Professional Paper 1286, US Geological Survey, Washington, D.C., 1984.
Williams, R. D., Measures R., Hicks, D. M., and Brasington, J.: Assessment of a numerical model to reproduce event-scale erosion and deposition distributions in a braided river, Water Resour. Res., 52, 6621-6642, https://doi.org/10.1002/2015WR018491, 2016.

Wohl, E.: What should these rivers look like? Historical range of variability and human impacts in the Colorado Front Range, USA, Earth Surf. Proc. Land., 36, 1378-1390, https://doi.org/10.1002/esp.2180, 2011.

Wohl, E., Bledsoe, B. P., Jacobson, R. B., Poff, N. L., Rathburn, S. L., Walters, D. M., and Wilcox, A. C.: The Natural Sediment Regime in Rivers: Broadening the Foundation for Ecosystem Management, Bioscience, 65, 358-371, https://doi.org/10.1093/biosci/biv002, 2015a.

Wohl, E., Lane, S. N., and Wilcox, A. C.: The science and practice of river restoration, Water Resour. Res., 51, 5974-5997, https://doi.org/10.1002/2014WR016874, 2015b.

Wong, J. S., Freer, J. E., Bates, P. D., Sear, D. A., and Stephens, E. M.: Sensitivity of a hydraulic model to channel erosion uncertainty during extreme flooding, Hydrol. Process., 29, 261-279, https://doi.org/10.1002/hyp.10148, 2015.

World Bank: Directions in hydropower, World Bank, Washington, D.C., available at: http://documents.worldbank.org/curated/en/ 164581468336679451/Directions-in-hydropower (last access: 19 June 2020), 2009.

Wu, W., Rodi, W., and Wenka, T.: 3D Numerical Modeling of Flow and Sediment Transport in Open Channels, J. Hydraul. Eng., 126, 4-15, https://doi.org/10.1061/(ASCE)07339429(2000)126:1(4), 2000.

Yin, X. A., Yang, Z. F., and Petts, G. E.: A New Method to Assess the Flow Regime Alterations in Riverine Ecosystems, River Res. Appl., 31, 497-504, https://doi.org/10.1002/rra.2817, 2015.

Zawiejska, J. and Wyżga, B.: Twentieth-century channel change on the Dunajec River, southern Poland: Patterns, causes and controls, Geomorphology, 117, 234-246, https://doi.org/10.1016/j.geomorph.2009.01.014, 2010.

Zhou, G., Wang, H., Shao, X., and Jia, D.: Numerical Model for Sediment Transport and Bed Degradation in the Yangtze River Channel Downstream of Three Gorges Reservoir, J. Hydraul. Eng., 135, 729-740, https://doi.org/10.1061/(ASCE)07339429(2009)135:9(729), 2009.

Ziliani, L. and Surian, N.: Evolutionary trajectory of channel morphology and controlling factors in a large gravel-bed river, Geomorphology, 173-174, 104-117, https://doi.org/10.1016/j.geomorph.2012.06.001, 2012.

Ziliani, L. and Surian, N.: Reconstructing temporal changes and prediction of channel evolution in a large Alpine river: the Tagliamento river, Italy, Aquat. Sci., 78, 83-94, https://doi.org/10.1007/s00027-015-0431-6, 2016.

Ziliani, L., Surian, N., Coulthard, T. J., and Tarantola, S.: Reduced-complexity modeling of braided rivers: assessing model performance by sensitivity analysis, calibration and validation, J. Geophys. Res.-Earth, 118, 2243-2262, https://doi.org/10.1002/jgrf.20154, 2013.

Zolezzi, G., Bellin, A., Bruno. M. C., Maiolini, B., and Siviglia, A.: Assessing hydrological alterations at multiple temporal scales: Adige River, Italy, Water Resour. Res., 45, W12421, https://doi.org/10.1029/2008WR007266, 2009. 
Zolezzi, G., Siviglia, A., Toffolon, M., and Maiolini, B.: Thermopeaking in alpine streams: Event characterization and time scales, Ecohydrology, 4, 564-576, https://doi.org/10.1002/eco.132, 2011. 